\title{
Linking The Securities MARKet Structure AND CAPITAL FORMATION: INCENTIVES FOR MARKET MAKERS?
}

\author{
Stanislav Dolgopolov*
}

This Article analyzes various incentives for market makers as a potential regulatory tool to address the interrelated crises in capital formation and market making in smaller-cap stocks. While considering the nature and development of the market making crisis and its impact on capital formation, such approaches as incentives for market makers conferring advantages in the trading process itself and issuer-to-market maker compensation arrangements are evaluated. The Article also addresses the significance of the integrated model of market making.

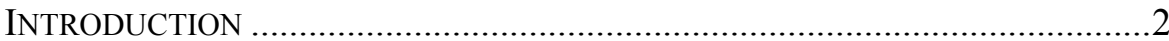

I. THE NATURE AND DEVELOPMENT OF THE MARKET MAKING

CRISIS AND ITS IMPACT ON CAPITAL FORMATION ..............................6

A. Early Warnings and the Recognition of the Problem ................... 7

B. Decimalization and Decreased Tick Sizes...................................11

C. Order Handling Rules..........................................................21

D. Blurring Boundaries Between Auction and Dealer Markets .....24

E. Cross-Subsidization of Market Making in Different

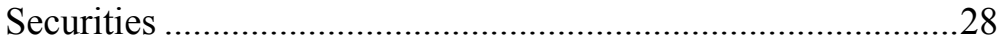

F. Other Functions Performed by Market Makers ..........................31

II. INCENTIVES FOR MARKET MAKERS CONFERRING ADVANTAGES

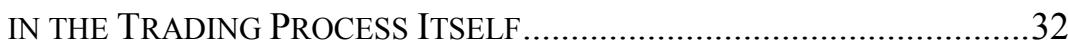

A. Time, Place, and Information Advantages ................................32

* J.D. (the University of Michigan), M.B.A. (the University of Chicago), B.S.B.A. (Drake University), member of the North Carolina State Bar. The author thanks Henry G. Manne for his guidance in life and Stephen M. Bainbridge, Harold Demsetz, Vladislav Dolgopolov, Mark F. Grady, Kate Im, and David Weild for their help, comments, and expertise. The support of the Lowell Milken Institute for Business Law and Policy at UCLA School of Law is gratefully acknowledged. 


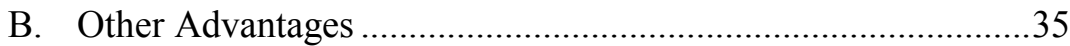

III.ISSUER-TO-MARKET MAKER COMPENSATION ARRANGEMENTS ............39

A. The Continuing Controversy …..................................................

B. The Rationale Behind the Underlying Mechanism ...................43

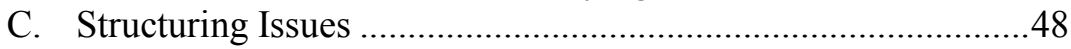

IV.INTEGRATED MODEL OF MARKET MAKING ........................................50

A. Bundling and the Economies of Scope .....................................50

B. Cross-Subsidization of Different Activities..............................52

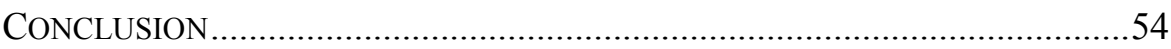

\section{INTRODUCTION}

The intertwined concerns over the capital formation crisis in the United States, the global competitiveness of its securities markets, and the distortionary effects of unequal access to capital have attracted a great deal of attention. ${ }^{1}$ One piece of the puzzle of the capital formation crisis is the deteriorating outlook for certain types of market makers - entities that provide liquidity under different names and in various forms - with the emphasis on the balance of their trading obligations and privileges and even the sufficiency of incentives for viable market making. ${ }^{2}$ The pain is

1. For a mix of sources illustrating these concerns and discussing a gamut of explanations, such as regulatory requirements for the issuance of securities, corporate governance aspects, and the architecture of the trading process, see The Future of Capital Formation: Hearing Before the H. Comm. on Oversight and Gov't Reform, 112th Cong. (2011); COMM. On CAPITAl MKts. Reg., InTERIM RePORT (Nov. 30, 2006), available at http://www.capmktsreg.org/pdfs/11.30Committee_Interim_ReportREV2.pdf; IPO TASK Force, Rebuilding the IPO ON-RAmp: Putting EMERGING COMPANIES AND THE JoB MARKET BACK ON THE ROAD TO GROWTH (Oct. 20, 2011), available at http://www.sec.gov/info/smallbus/acsec/rebuilding_the_ipo_on-ramp.pdf; MCKINSEY \& Co. $\&$ N.Y. City ECON. Dev. CorP., Sustaining New YorK's AND the US' Global Financial SERVICES LEADERSHIP (2007), available at www.nyc.gov/html/om/pdf/ny_report_final.pdf; NAT'L AdVISORY COUNCIL ON INNOVATION \& ENTREPRENEURShIP, U.S. DEP'T OF COMmerce, Report to SeCretary Locke: Improving ACCess to CAPITAl For HighGROWTH COMPANIES (June 2011), available at http://www.cdfa.net/cdfa/cdfaweb.nsf/ordredirect.html?open\&id=doc_high-

growth_report.html; DAVID WEILD \& EDWARD KIM, GRANT THORNTON LLP, MARKET Structure Is CAUSING THE IPO CRISIS - AND MORE (June 2010), available at http://www.grantthornton.com/staticfiles/GTCom/Public\%20companies\%20and\%20capital \%20markets/Files/IPO\%20crisis\%20-\%20June\%202010\%20-\%20FINAL.pdf; Robert E. Grady, The Sarbox Monster, WALl ST. J., Apr. 26, 2007, at A19; Harold Bradley \& Robert E. Litan, Choking the Recovery: Why New Growth Companies Aren't Going Public and Unrecognized Risks of Future Market Disruptions (Nov. 12, 2010) (unpublished manuscript) (on file with author), available at http://www.kauffman.org/uploadedFiles/etf_study_11-8-10.pdf.

2. See, e.g., Dark Pools, Flash Orders, High-Frequency Trading, and Other Market Structure Issues: Hearing Before the Subcomm. on Sec., Ins., \& Inv. of the S. Comm. on Banking, Hous., \& Urban Affairs, 111th Cong. 85 (2009) [hereinafter Senate Hearing on 
particularly felt by providers of liquidity in smaller-cap stocks, which tend to be less frequently traded than large-cap stocks and represent the bulk of emerging companies. ${ }^{3}$ As one securities industry professional has recently observed, "[T]he horrible economics of providing small- and mid-cap liquidity [is] chasing away market makers." ${ }^{4}$ This development is troubling in light of its potential impact on liquidity governed by its own forces of supply and demand and, accordingly, the capital formation process. After all, liquidity, which is a multifaceted concept ${ }^{5}$ is an important determinant of any asset's price. ${ }^{6}$

Another concern is the regulatory regime for providers of liquidity principally set by the U.S. Securities and Exchange Commissions ("SEC") under the mandate of the federal securities statutes and trading venues as self-regulatory organizations ("SROs"). Without being a panacea for every ill, this regime may aid the capital formation ecosystem. In other words,

Market Structure Issues] (prepared testimony of Peter Driscoll, Chairman, Securities Traders Association) ("[Market makers] retained all of their obligations to the market... but the rewards for these obligations were cut dramatically. Traditional market making became unprofitable and most market making firms reduced their market making activity or bowed out of the business altogether."); SEC. TRADERS Ass'N, THE STA's PERSPECTIVE ON U.S. MARKET STRUCTURE 6 (May 2008), available at http://www.securitytraders.org/wpcontent/uploads/2012/10/STA-WHITE-PAPER2008.pdf ("Market making incentives are no longer valuable enough to incentivize participants to risk their capital.").

3. Although there is quite a bit of overlap between stocks of emerging companies, smaller-cap stocks, and less frequently traded stocks, these categories are by no means identical.

4. Larry Tabb, Restarting the Engines of Growth, TABB FoRUM (Apr. 20, 2011), $\mathrm{http}: / /$ tabbforum.com/opinions/restarting-the-engines-of-growth (registration required).

5. For recent sources on different dimensions of liquidity, see Michael Aitken \& Carole Comerton-Forde, How Should Liquidity Be Measured?, 11 PAC.-BASIN FIN. J. 45 (2003); Ruslan Y. Goyenko et al., Do Liquidity Measures Measure Liquidity?, 92 J. FIN. ECON. 153 (2009); Sriketan Mahanti et al., Latent Liquidity: A New Measure of Liquidity, with an Application to Corporate Bonds, 88 J. FIN. ECON. 272 (2008); Alexandros Gabrielsen et al., Measuring Market Liquidity: An Introductory Survey (Dep't of Econ., Univ. of Bologna, Working Paper DSE No. 802, 2011), available at http://ssrn.com/abstract=1976149.

6. For recent sources on the impact of liquidity on asset prices and hence firm value, see Viral V. Acharya \& Lasse Heje Pedersen, Asset Pricing with Liquidity Risk, 77 J. FIN. ECON. 375 (2005); Yakov Amihud \& Haim Mendelson, Liquidity, the Value of the Firm, and Corporate Finance, J. ApPlied CORP. Fin., Spring 2008, at 32; Stanley Block, The Liquidity Discount in Valuing Privately Owned Companies, J. ApPLIED FIN., Fall / Winter 2007, at 33; Vivian W. Fang et al., Stock Market Liquidity and Firm Value, 94 J. FIN. ECON. 150 (2009). In fact, an analysis of the emergence of one of the earliest-known groups of equity market makers in the 17th century concluded that "[t]he appearance of market makers coincided with a rapid increase in the share price and in trading activity on the securities market in Amsterdam [and] [t] hese three events were interrelated." Lodewijk Petram, The World's First Stock Exchange: How the Amsterdam Market for Dutch East India Company Shares Became a Modern Securities Market, 1602-1700, at 40 (2011) (unpublished Ph.D. dissertation, Univ. of Amsterdam) (on file with author), available at http://dare.uva.nl/document/201694. 
this inquiry, which is hardly novel but still relevant, addresses incentives for market makers allowed - or specifically provided - by the regulatory regime as one of the links between the securities market structure and capital formation.

Going even further than the level of liquidity of existing securities in a static framework, a key issue is the relationship between the viability of market making in securities of emerging companies and the process of capital formation. After all, as articulated decades ago, "[T]he maintenance of a liquid, or immediately accessible, market to the investor . . . in turn means an opportunity for the nation's industry to finance its development . ... [T] he specialist [as a market maker] performs an essential function in that branch of national economy.",

A closely related issue is the externality embedded in the economics of providing liquidity, which is of particular importance for smaller-cap stocks: "In general, liquidity provision represents a positive externality in that traders who commit capital to make markets are not fully compensated for their liquidity services. While the usual solution to this inefficiency is a Pigovian subsidy, the form that this payment should take is less clear." There are different theoretical approaches to the nature of this externality. ${ }^{9}$

7. Stock Exchange Practices: Hearings Before the S. Comm. on Banking \& Currency, 73d Cong. pt. 16, at 7749 (1934) (Petition on Behalf of the Specialists of the New York Stock Exchange (Mar. 24, 1934)).

8. Kumar Venkataraman \& Andrew C. Waisburd, The Value of the Designated Market Maker, 42 J. Fin. \& QuANT. ANALYsis 735, 755 (2007).

9. See Kalman J. Cohen et al., The Impact of Designated Market Makers on Security Prices, 1 J. BANKING \& FIN. 219, 237, 245 (1977) ("[Price] stabilization [by designated market makers] is a public good type external economy to investors... [and it] would be internalized in a free market where contracts between corporations and stabilizers are not restricted.”); Jennifer Huang \& Jiang Wang, Market Liquidity, Asset Prices, and Welfare, 95 J. FIN. ECON. 107, 109 (2010) ("In our model, trading and liquidity provision generate externalities. A trader's participation in the market also benefits his potential counterparties, and a market maker's supply of liquidity helps all potential traders. . . . [I]n general, market mechanism fails to properly internalize these externalities and thus leads to inefficient supply of liquidity in the market."); Wen Mao \& Michael S. Pagano, Specialists as Risk Managers: The Competition Between Intermediated and Non-Intermediated Markets, $35 \mathrm{~J}$. BANKING \& FIN. 51, 64 (2011) (“A specialist's [order execution] risk management service has some attributes of a public good.... If specialists cannot recoup the full value of this service directly from their market-making activities, then ... all market participants might benefit if some form of institutional support was provided to these specialists . ..."); Albert J. Menkveld, Market Quality Program Proposal NASDAQ (SR-NASDAQ-2012-043): A Comment 2 (May 2, 2012) (unpublished manuscript) (on file with author), available at http://www.sec.gov/comments/sr-nasdaq-2012-043/nasdaq2012043-12.pdf ("If, at launch, a particular security's liquidity supply is uncertain, investors might be trapped in a 'bad equilibrium' [but if] future liquidity is less uncertain, and investors participate; the 'good equilibrium' is reached. This participation externality is well-understood in the finance literature ....”); Johannes A. Skjeltorp \& Bernt Arne Ødegaard, Why Do Listed Firms Pay for Market Making in Their Own Stock? 16, 30 (May 2012) (unpublished manuscript) (on 
For instance, issuers that do not participate in secondary trading cannot be excluded from enjoying the potential benefits of additional liquidity, which may affect operating decisions of such companies and hence the real economy. Another explanation may be based on the trading process itself with respect to different types of actual or potential participants in this process, and this explanation is also consistent with an impact on issuers and the real economy. Furthermore, several empirical studies indicate that the existence of trading obligations applicable to market makers - coupled with certain privileges - improves market quality. ${ }^{10}$ This phenomenon suggests gains in economic efficiency, rather than mere wealth transfers. ${ }^{11}$ On the other hand, there is some skepticism that designated market makers, as opposed to their informal counterparts with no trading obligations and privileges are desirable - or need substantial incentives-for liquid securities. ${ }^{12}$ Still, the point of view that questions the desirability of trading

file with author), available at http://ssrn.com/abstract=1944057 ("[T]here may be an externality from hiring a [designated market maker by an issuer] in the sense that 'liquidity attracts liquidity.' ... [G]iven the public goods nature of liquidity . . . it may be desirable to subsidize liquidity provision in equity markets.").

10. See, e.g., Amber Anand \& Daniel G. Weaver, The Value of the Specialist: Empirical Evidence from the CBOE, 9 J. FIN. MKTS. 100, 102-04 (2006) (analyzing transactions in equity options on the Chicago Board Options Exchange after the introduction of designated primary market makers, entities with affirmative obligations and informational and order flow allocation privileges, and finding an improvement in market quality); Rafi Eldor et al., The Contribution of Market Makers to Liquidity and Efficiency of Options Trading in Electronic Markets, 30 J. BANKING \& FIN. 2025, 2025, 2029-31 (2006) (analyzing transactions in foreign exchange rate options on the Tel Aviv Stock Exchange after the introduction of market makers, entities with affirmative obligations that receive rebates on trading and clearance fees together with direct cash payments from the trading venue, and finding an improvement in market quality and efficiency); M. Nimalendran \& Giovanni Petrella, Do Thinly-Traded Stocks Benefit from Specialist Intervention?, 27 J. BANKING \& FIN. 1823, 1829-30, 1851-52 (2003) (analyzing transactions in stocks on the Italian Stock Exchange and finding that the existence of specialists, entities with affirmative obligations that pay lower trading fees and may be compensated by issuers, is associated with improved market quality); Angelo Aspris et al., The Impact of the Introduction of Mandated Market Makers on Transaction Costs: Evidence from the Sydney Futures Exchange 2-5 (n.d.) (unpublished manuscript) (on file with author) (analyzing transactions in options on government securities on the Sydney Futures Exchange after the introduction of designated market makers, entities with affirmative obligations that receive fee discounts and direct cash payments from the trading venue, and finding improved market quality).

11. For instance, one study analyzing transactions in foreign exchange rate options on the Tel Aviv Stock Exchange estimated that "for every dollar spent by the exchange [to subsidize designated market makers], there are $\$ 67$ [in] benefits to the public trading in this market [in the form of lower transaction costs]." Eldor et al., supra note 10, at 2031. Keeping in mind the limitations of empirical studies, as well as the need for further research, this multiplier is quite impressive. Another study analyzing transactions in stocks on the Oslo Stock Exchange similarly concluded that "on average the required return for firms that hire a [designated market maker compensated by an issuer] is reduced by about $3 \%$ in annualized terms." Skjeltorp \& Ødegaard, supra note 9, at 28.

12. For one of the earliest discussions touching on this argument, see Jack Hirshleifer, 
obligations of market makers as $\operatorname{such}^{13}$ - and perhaps focuses on scenarios of extreme market volatility-is misguided.

This Article analyzes various incentives for market makers as a potential regulatory tool to address the intertwined crises in capital formation and market making in smaller-cap stocks. Part I considers the nature and development of the market making crisis and its impact on capital formation. Part II examines incentives for market makers conferring advantages in the trading process itself. Part III examines issuer-to-market maker compensation arrangements. Part IV considers the significance of the integrated model of market making. The Article concludes by evaluating the utility and desirability of incentives for market makers as one of the approaches to the capital formation crisis and by putting this issue in the context of broader reforms of the securities market structure for emerging companies.

\section{The NATURE AND DEVElopMent OF THE MARKET MAKING}

Reflections on the Role and Functioning of the Organized Exchanges 9-11 (RAND Corp., Paper No. P-4666, 1971). As an illustration, a recent empirical study analyzed transactions in stocks on the Toronto Stock Exchange and concluded that the presence of designated market makers is of less importance for large-cap stocks, in which liquidity is to a large degree provided by de facto market makers, while the latter category's "business model is generally not supportive of active participation in less liquid segments of the market." Amber Anand \& Kumar Venkataraman, Should Exchanges Impose Market Maker Obligations? 16-17, 28 (July 2013) (unpublished manuscript) (on file with author), available at http://ssrn.com/abstract=2179259. These results "point to a mechanism by which a [designated market maker] structure meets the needs of investors and increases the firm value." $I d$. at 28 . Some commentators hold the view that liquidity in liquid securities is provided by high-frequency traders. See, e.g., Senate Hearing on Market Structure Issues, supra note 2, at 87 (prepared testimony of Peter Driscoll, Chairman, Securities Traders Association) ("We believe that there is a need for market making in secondary and tertiary issues, but not necessarily the primary tier stocks where data suggests most high frequency traders concentrate their activity."). On the other hand, the role of high-frequency traders as liquidity providers vis-à-vis designated market makers is a matter for debate-even for liquid securities. See Stanislav Dolgopolov, Providing Liquidity in a High-Frequency World: Trading Obligations and Privileges of Market Makers and a Private Right of Action, 7 Brook. J. Corp. Fin. \& COM. L. 303, 346-48 \& nn.228-36 (2013).

13. See, e.g., Examining the Efficiency, Stability, and Integrity of the U.S. Capital Markets: Joint Hearing Before the Subcomm. on Sec., Ins., \& Inv. of the S. Comm. on Banking, Hous., \& Urban Affairs and the Permanent Subcomm. on Investigations of the S. Comm. on Homeland Sec. \& Governmental Affairs, 111th Cong. 41 (2011) (remarks of Manoj Narang, Chief Executive Officer, Tradeworx, Inc.) ("I cannot think of any empirical evidence that market maker obligations actually matter in practice.”); Hans R. Stoll, Reconsidering the Affirmative Obligation of Market Makers, FIN. ANALYSTS J., Sept. / Oct. 1998 , at 72, 80 ("That an affirmative obligation reduces volatility or makes markets more efficient is not evident... Markets will function well without an affirmative obligation. Market makers need no regulatory obligations and should not receive special privileges."); Bradley \& Litan, supra note 1, at 66 ("History shows that affirmative obligations affirm only intermediaries' profits."). 


\section{CRISIS AND ITS IMPACT ON CAPITAL FORMATION}

The nature and development of the market making crisis and its impact on capital formation should be viewed from a variety of perspectives. Different causal links traced to various regulatory, technological, and economic developments, as well as their cumulative effect, are relevant, and many of them appear to be largely unintended and unanticipated.

\section{A. Early Warnings and the Recognition of the Problem}

With the securities market structure's transformational leap beginning in the 1990s, some experts questioned its impact on smaller-cap stocks, focusing on the viability of market making:

In the past few years, technology and regulatory change has caused rapid, dramatic, and unprecedented changes in the equity trading markets. While all these developments are worthy of appropriate regulatory reforms, the highly successful dealer markets servicing small issuers must not be sacrificed. Too often, however, regulatory reforms have been shaped almost exclusively by the analysis of the top tier of the market, consisting mostly of the most actively traded securities in U.S. equity markets. ... The potential erosion of the small issuer equity market is a growing concern for small business entrepreneurs in every region of the country. . . . If changes in market structure adversely affect the small cap markets and the market makers [sic] ability to service them, the venture capital stream will likely dry up. ${ }^{14}$

Only several years later, these fears were confirmed by the exChairman of the National Venture Capital Association:

For three decades, venture capital-backed startup companies have been the job-creating engine of the U.S. economy. . . . Today, however, we are killing that job-creating engine with a combination of high transaction costs and tremendous friction that is hampering our capital markets, particularly the Nasdaq. These problems are the unintended consequences of a bevy of regulations [that] wrung all the economics out of Nasdaq market-

14. Competition in the New Electronic Market: Hearings Before the Subcomm. on Fin. \& Hazardous Materials of the H. Comm. on Commerce, 106th Cong. 111 (2000) [hereinafter House Hearing on Competition in the New Electronic Market] (testimony of Kenneth A. Kamen, Executive Vice President, Princeton Securities Corporation, and Chairman of the Board of Directors, Regional Investment Bankers Association) (emphasis added). 
making and small cap sell-side equity research. ${ }^{15}$

Indeed, one of the chief causes of the capital formation crisis is the decreased level of liquidity for smaller-cap stocks, which is at least partly traced to the market making crisis.Overall, decreased potential demand for such securities in public markets is a real concern:

The last decade has shown a significant decrease in the trading liquidity for most small cap issuers [and] portfolio managers carefully assess liquidity when determining position size and price as they know it may be hard to get out of the stock when their price targets are reached or should they need to sell to generate liquidity to meet investor redemptions. This dynamic has severely narrowed the investor universe for small cap companies thereby making it difficult for them to raise capital to expand. ${ }^{16}$

An analogous concern arises out of the disproportionate impact of recent technological changes in securities markets, such as the continuing increase in high-frequency trading, on the smaller-cap end of the spectrum: "[S]mall- and mid-cap . . . stocks don't have sufficient liquidity for the high-frequency-type automated traders to traffic in those names, and as a result, you have not seen a commensurate level of volume or liquidity or spread compression that you have seen in some of the large-cap names." ${ }^{\prime 17}$

15. Grady, supra note 1.

16. Market Structure: Ensuring Orderly, Efficient, Innovative and Competitive Markets for Issuers and Investors: Hearing Before the Subcomm. on Capital Mkts. \& Gov't Sponsored Enters. of the H. Comm. on Fin. Servs., 112th Cong. 164 (2012) [hereinafter House Hearing on Market Structure] (prepared testimony of Jeffrey M. Solomon, Chief Executive Officer, Cowen and Company, LLC); see also How Roadblocks in Public Markets Prevent Job Creation on Main Street: Hearing Before the Subcomm. on TARP, Fin. Servs. \& Bailouts of Pub. \& Private Programs of the H. Comm. on Oversight \& Gov't Reform, 112th Cong. 18 (2012) [hereinafter House Hearing on Roadblocks in Public Markets] (testimony of Joseph Mecane, Executive Vice President and Chief Administrative Officer, U.S. Markets, NYSE Euronext) ("Companies with small capitalizations consistently raise two concerns about going public as it relates to market structure. First, whether there will be sufficient liquidity in my stock; and second, will I have sufficient analyst coverage?"); WEILD \& KIM, supra note 1, at 7 ("While there is an array of liquidity options ... most of these options have their own limitations and satisfy only a small fraction of liquidity needs. As a result, most companies today never make it public. Instead, the exit workhorse of venture capital is now the sale of a portfolio company to mostly strategic (large corporate) acquirers.").

17. House Hearing on Roadblocks in Public Markets, supra note 16, at 29 (remarks of Joseph Mecane, Executive Vice President and Chief Administrative Officer, U.S. Markets, NYSE Euronext); see also Nataliya Bershova \& Dmitry Rakhlin, High-Frequency Trading and Long-Term Investors: A View from the Buy-Side, J. InV. STRATEGIES, Spring 2013, at 3, 44 ("Traders should also realize how quickly available liquidity drops below the top 50-70 stocks and keep significantly more flexibility and clear price targets to execute less liquid orders."). This disproportionate effect on the liquidity of smaller-cap stocks was recognized as a potential problem by the SEC leadership relatively early. See, e.g., Reviewing U.S. 
Of course, these developments are likely to create a more difficult environment for smaller companies going public-for instance, via decreased demand from institutional investors. ${ }^{18}$ In fact, despite recent blockbuster IPOs, less glamorous companies seem unable or unwilling to go public, an attitude that is likely related to the liquidity factor: "[While] a number of very large companies [have gone] public ... this year . . . much of that IPO activity [is] concentrated with the large-cap stocks and not with some of the small- and mid-cap stocks that we have seen historically." 19 More saliently, the unfriendliness of public markets to smaller companies has broader consequences for the real economy:

When IPO capital formation is restricted, entrepreneurs are incented to create products which complement existing products of large companies, rather than creating transformational products which change the way we live, work and think. Entrepreneurs are forced to sell their ideas too cheaply in the private markets. ... In the broadest terms, resources are inefficiently allocated, growth is negatively impacted, and the economy falls short of its potential. ${ }^{20}$

Capital Market Structure-Promoting Competition in a Changing Trading Environment: Hearing Before the Subcomm. on Capital Mkts., Ins. \& Gov't Sponsored Enters. of the H. Comm. on Fin. Servs., 108th Cong. 27 (2003) (remarks of William H. Donaldson, Chairman of the U.S. Securities and Exchange Commission) ("It is quite possible that we have had a reduced liquidity in lesser-traded stocks that market-makers are less inclined to commit their capital with less of a profit margin available to them.").

18. See, e.g., Spurring Job Growth Through Capital Formation While Protecting Investors - Part I: Hearing Before the S. Comm. on Banking, Hous., \& Urban Affairs, 112th Cong. 62 (2013) [hereinafter Senate Hearing on Spurring Job Growth Through Capital Formation I] (prepared testimony of John C. Coffee, Jr. Adolf A. Berle Professor of Law Columbia University Law School) ("Institutional investors are the primary buyers of IPOs, but institutional investors want secondary market liquidity, and they can rarely obtain such liquidity unless the market capitalization of the IPO issuer is equal to $\$ 500$ million or more....").

19. House Hearing on Roadblocks in Public Markets, supra note 16, at 32 (testimony of Joseph Mecane, Executive Vice President and Chief Administrative Officer, U.S. Markets, NYSE Euronext). On the other hand, one empirical study has questioned whether various institutional and regulatory impediments to going public really matter much and suggested that "the drop in small company IPO activity is due to the lack of profitability of small stand-alone businesses relative to their value as part of a larger organization." Spurring Job Growth Through Capital Formation While Protecting Investors, Part II: Hearing Before the S. Comm. on Banking, Hous., \& Urban Affairs, 112th Cong. 41 (2013) (prepared testimony of Jay R. Ritter, Cordell Professor of Finance, Warrington College of Business Administration, University of Florida). The study in question is Xiaohui Gao et al., Where Have All the IPOs Gone?, J. FIN. \& QUANT. ANALYSIS (forthcoming), available at http://ssrn.com/abstract=1954788.

20. Senate Hearing on Spurring Job Growth Through Capital Formation I, supra note 18, at 74 (prepared testimony of Edward S. Knight, General Counsel and Executive Vice President, NASDAQ OMX Group). 
Even the much-publicized "private secondary markets" 21 occupy a special niche and hardly serve as a substitute for public markets. For instance, secondary private markets have inherent limitations on their level of liquidity, such as regulatory restrictions on the number and identity of security holders and holding periods. ${ }^{22}$ Furthermore, these trading platforms tend to be matching networks that lack specialized participants that provide liquidity, as the regulatory framework leaves little room for such participants. ${ }^{23}$ As one critic noted, "These private secondary markets give the illusion, but not the reality, of liquidity. They are matching systems, and the broker does not function as a dealer committing its own capital." ${ }^{24}$ In the same fashion, even going public on a foreign alternative

21. For an overview of private secondary markets, see Elizabeth Pollman, Information Issues on Wall Street 2.0, 161 U. PA. L. REV. 179 (2012); Jeremy Drean, The Secondary Private Markets - New Players in the Venture Capital Ecosystem (2011) (unpublished manuscript) (on file with author); Oren Livne, Secondary Markets for Private Company Shares: Marketplace Overview and Predictive Capability (Apr. 2, 2012) (unpublished manuscript) (on file with author).

22. For an overview of the regulatory framework governing secondary private markets and the applicable restrictions that limit liquidity, see Pollman, supra note 21, at 187-93; Jeff Schwartz, The Twilight of Equity Liquidity, 34 CARDOzo L. REV. 531, 550-63 (2012). As one commentator has remarked, these trading platforms "are built on a regulatory foundation, and the exemptions upon which these markets are founded are ill-suited to support healthy liquidity platforms." Schwartz, supra, at 551.

23. For a discussion of how several exemptions commonly used by secondary private markets are unavailable to dealers in general, see Memorandum from Annemarie Tierney, Gen. Counsel, SecondMarket, to Private Co. Internal and External Counsel 3-4 (Sept. 12, 2011), available at http://www.secondmarket.com/education/wpcontent/uploads/2013/02/Memo-on-SecondMarkets-Legal-Framework-SecondMarket.pdf. For instance, one common exemption, Rule 144, Persons Deemed Not To Be Engaged in a Distribution and Therefore Not Underwriters, 17 C.F.R. $\S 230.144$ (2012), references market makers in the manner of sale requirements, but this exemption specifically limits its application to "'a person other than an issuer, underwriter, or dealer" " under section 4(a)(1) - formerly section 4(1) — of the Securities Act of 1933 ("Securities Act"). On the other hand, certain exemptions allow for the existence of liquidity providers in secondary private markets. For example, PORTAL Alliance, a trading platform geared towards large institutional investors in reliance on Rule 144A, Private Resales of Securities to Institutions, 17 C.F.R. § 230.144A (2012), has market makers. PORTAL Alliance, http://www.portalalliancemarket.com (follow "OTC Trading Process" hyperlink) (last visited Mar. 10, 2013). By contrast to Rule 144, Rule 144A generally relies on section 5 of the Securities Act, specifically permits dealer participation, and has less stringent restrictions on the turnover of securities, such as a minimum holding period. For the SEC's discussion of the statutory basis for Rule 144A under the Securities Act with respect to dealers, see Resale of Restricted Securities, Securities Act Release No. 6862, Exchange Act Release No. 27,928, Investment Company Act Release No. 17,452, 55 Fed. Reg. 17,933, 17,934-35 (Apr. 23, 1990).

24. Richard Teitelbaum, Facebook Drives Second Market Broking \$1 Billion Private Shares, BLOOMBERG MARKETS (Apr. 27, 2011), http://www.bloomberg.com/news/print/2011-04-27/facebook-drives-secondmarket-broking1-billion-private-shares.html (quoting Professor John Coffee, Columbia Law School). 
market is deemed an undesirable option for the lack of liquidity. ${ }^{25}$

A number of specific explanations have been proposed for the connection between the market making and capital formation crises, including decimalization, order handling rules, and restrictions on compensation methods of securities analysts. ${ }^{26}$ While some of these explanations are connected to market making techniques, others touch on the integrated model of market making employed by many securities firms. Furthermore, while the rise of high-frequency trading and the increased reliance on proprietary trading by securities firms may have contributed to the crisis in market making in smaller-cap stocks in terms of outflow of capital, ${ }^{27}$ this factor alone cannot be a sufficient explanation in the world of cutthroat competition in all trading strata. ${ }^{28}$

\section{B. Decimalization and Decreased Tick Sizes}

Some see decimalization, the switch to price quotations in cents rather than dollar fractions, which was often accompanied by the adoption of a penny "tick size" / "minimum price variation," as one of the pivotal links between the market making and capital formation crises. One influential policy paper called decimalization a "death star," concluding that its impact on "the economics from the trading spread of most small cap stocks . . .

25. See H.R. 3606, The Reopening American Capital Markets to Emerging Growth Companies Act of 2011: Hearing Before the Subcomm. on Capital Mkts. \& Gov't Sponsored Enters. of the H. Comm. on Fin. Servs., 112th Cong. 15 (2012) [hereinafter House Hearings on H.R. 3606] (remarks of Joseph Brantuk, Vice President, NASDAQ OMX Group); WeILD \& KIM, supra note 1 , at 7.

26. See, e.g., House Hearings on H.R. 3606, supra note 25, at 62 (prepared testimony of Kate Mitchell, Managing Director and Co-Founder, Scale Venture Partners, and former Chairman and current member, National Venture Capital Association); WeILD \& KIM, supra note 1, at 11-14; Grady, supra note 1.

27. For a related discussion, see IPO TASK FORCE, supra note 1, at 13-14. Interestingly, one empirical study concluded that "greater... intensity [of algorithmic trading, as a precondition for high-frequency trading] in small firms increases transactions costs and therefore reduces liquidity in these firms." Ekkehart Boehmer et al., International Evidence on Algorithmic Trading (Mar. 14, 2012) (unpublished manuscript) (on file with author), available at http://ssrn.com/abstract=2022034. In other words, there may be a different channel transmitting the impact of high-frequency trading.

28. See, e.g., Matthew Philips, How High-Speed Traders Outraced the Profits, BLOOMBERG BUSINESSWEeK (Oct. 16, 2012), http://www.businessweek.com/articles/201210-16/how-high-speed-traders-outraced-the-

profits?goback=.gde_2330028_member_176048675 ("In an ironic twist, high-frequency traders have gotten so fast, they seem to have outrun their own profitability."); Letter from Daniel Trinder, Regulatory Affairs Dep't, Deutsche Bank, to the Comm. of Eur. Sec. Regulators, 2 (May 4, 2010), available at http://www.esma.europa.eu/system/files/1DBG_for_publication.pdf ("We believe that the market share of [high-frequency trading] will reach a natural plateau in the near future due to the limited potential profitability of these strategies."). 
was too great a shock for the system to bear." ${ }^{29}$ The JOBS Act of 2012 responded to this argument by mandating a special report to "examine the impact that decimalization has had on the number of initial public offerings [and] liquidity for small and middle capitalization company securities and whether there is sufficient economic incentive to support trading operations in these securities in penny increments." ${ }^{30}$ The SEC staff completed this report within the short time window prescribed by the statute, ${ }^{31}$ and the decimalization and tick size issues remain on the regulatory agency's agenda. $^{32}$

In fact, in the early 1990s, the SEC considered switching from the traditional system of non-decimal dollar fractions to a decimal system, prompting the (later) infamous Bernard L. Madoff to opine that "tighter spreads [as a result of decimalization] would add to liquidity and trading volume. (But) there is a point where the spreads could become too narrow, and that could discourage market makers from taking risks." ${ }^{33}$ In 1994, an SEC study summarily dismissed the argument that "narrower quote variations could lead market makers and exchange specialists to abandon infrequently traded stocks, and thereby reduce liquidity for those stocks [and] cause some dealers to cease doing business," maintaining that "[t]here is no justification to continue subsidizing, through artificially wide spreads, dealers who may not be operating efficiently." ${ }^{34}$

29. WEILD \& KIM, supra note 1 , at 11 .

30. Jumpstart Our Business Startups Act, Pub. L. No. 112-106, § 106(b), 126 Stat. 306, 312 (2012).

31. Staff, U.S. Sec. \& Exch. Comm'n, Report to Congress on Decimalization (July 2012), available at http://www.sec.gov/news/studies/2012/decimalization-072012.pdf [hereinafter SEC STAFF's DECIMALIZATION REPORT].

32. See Letter from Stephen M. Graham \& M. Christine Jacobs, SEC Advisory Comm. on Small \& Emerging Cos., to Comm. Members 1 (Jan. 2013), available at $\mathrm{http}: / / \mathrm{www} . \mathrm{sec}$.gov/info/smallbus/acsec/draft-committee-recommendations-statement020113.pdf (stating that "the consensus of the committee" was to recommend to the SEC to "[i]mmediately provide for a meaningful increase in tick size as a necessary step toward encouraging the reestablishment of an infrastructure designed to increase liquidity for small public companies"); Press Release No. 2012-274, U.S. Sec. \& Exch. Comm'n, SEC Announces Agenda for Roundtable on Decimalization (Dec. 21, 2012), available at http://www.sec.gov/news/press/2012/2012-274.htm (describing the agenda and soliciting public feedback).

33. Victor F. Zonana, SEC Weighs Decimal Stock Pricing System, L.A. TiMES, June 13, 1991, at D2.

34. Div. of Mkt. Regulation, U.S. Sec. \& Exch. Comm'n, Market 2000: AN EXAminAtion of CURRENT EQuity MARKet DeVelopments, at IV-9 (Jan. 1994), available at http://www.sec.gov/divisions/marketreg/market2000.pdf. The regulatory agency effectively recognized that some profits from large tick sizes may be dissipated by other factors, such as the practice of payment for order flow. Id. at 18, IV-9. Furthermore, there could be some debate whether larger tick sizes are "undercut" via internalization and preferencing by individual broker-dealers. See David C. Porter \& Daniel G. Weaver, Tick Size and Market Quality, Fin. MGMT., Winter 1997, at 5, 25. 
In 2000 , the regulatory agency orchestrated a transition to a decimal system, ${ }^{35}$ although not immediately accompanied by a penny tick size in all markets. ${ }^{36}$ As predicted, underlying forces pushed all trading venues to embrace the smallest tick size possible: "In practice, the best execution principles will require all exchanges and trading systems to adopt the smallest minimum price increment that any of them adopt. Otherwise, those that adopt larger increment [sic] will not be able to obtain order flow when another exchange has a slightly better price. ${ }^{37}$ Even in the absence of the best execution standard, trading venues are tempted to follow the same course of action in order to gain market share at the expense of competitors, which might "result[] in an overall reduction in investor protection and a degradation of market quality." 38

One approach to the impact of decimalization is to treat large tick sizes as a subsidy to market makers. However, the connection between a smaller tick size and decreased liquidity or even the exit of cost-efficient market making firms - as opposed to dissipated rents - appears puzzling. After all, a bid-ask spread does not have to converge to just one tick. ${ }^{39}$

35. See Order Directing the Exchanges and the National Association of Securities Dealers, Inc. To Submit a Phase-in Plan To Implement Decimal Pricing in Equity Securities and Options, Exchange Act Release No. 42,914, 65 Fed. Reg. 38,010 (June 8, 2000); Order Directing the Exchanges and the National Association of Securities Dealers, Inc. To Submit a Decimalization Implementation Plan, Exchange Act Release No. 42,360, 65 Fed. Reg. 5003 (Jan. 28, 2000); see also Exch. Comm. on Decimals, Decimals Implementation Plan for the Equities and Options Markets (July 24, 2000), available at http://www.sec.gov/rules/other/decimalp.htm. For a further regulatory history of decimalization, see SEC STAFF's DECIMALIZATION REPORT, supra note 31, at 4-5.

36. See, e.g., Order Approving a Proposed Rule Change by Chicago Board Options Exchange, Inc. Relating to the Penny Pilot Program, Exchange Act Release No. 55,154, 72 Fed. Reg. 4743, 4743-44 (Jan. 23, 2007) (approving a penny tick size for certain options and stating that "all six options exchanges [currently] quote options in nickel and dime increments"); see also Press Release No. 2007-10, U.S. Sec. \& Exch. Comm'n, Options Exchanges Begin Penny Quoting Pilot (Jan. 26, 2007), available at http://www.sec.gov/news/press/2007/2007-10.htm (describing the adoption of a penny tick size by all options exchanges for certain options and the SEC's role in this development).

37. Lawrence Harris, Trading in Pennies: A Survey of the Issues 10-11 (Nov. 15, 1999) (unpublished manuscript) (on file with author), available at http://wwwbcf.usc.edu/ lharris/ACROBAT/pennies.pdf; see also id. at 11 ("The resulting competitive solution in which all markets trade on the smallest price increment chosen by any market probably is a poor solution because it does not address the externality problem associated with the exposure of orders.").

38. James J. Angel, Tick Size Regulation: Costs, Benefits, and Risks 3 (U.K. Gov’t Office for Sci., The Future of Computer Trading in Financial Markets - Foresight, Economic Impact Assessment No. 7, 2012), available at http://www.bis.gov.uk/assets/foresight/docs/computer-trading/12-1068-eia7-tick-sizeregulation-costs-benefits.pdf.

39. Several empirical studies are consistent with the hypothesis that a smaller tick size affects economic rents of market makers without any serious adverse effects on liquidity, although these studies focused on short-term effects. See Hee-Joon Ahn et al., Tick Size, 
Decimalization, by itself, sets a price grid, but it does not mandate a maximum bid-ask spread. While an economically significant tick size may compensate market makers for their fixed costs, ${ }^{40}$ the paradigm of "destructive competition" among market makers still seems problematic. ${ }^{41}$ Overall, the impact of decimalization seems to have been subtle, and it should be analyzed in conjunction with other developments, such as competition from public limit orders. ${ }^{42}$

More generally, as an executive of a market making firm observed in the aftermath of decimalization,

Today's one-penny [minimum price variation] has reduced price discovery, diminished liquidity and increased the level of trading activity required to execute an entire order. No market participant has an incentive to quote in size, as others can easily coopt that information and trade ahead by as little as one penny. .

Spread, and Volume, 5 J. Fin. INTERMEDIATION 2, 16, 21 (1996) ("[T]he evidence from the post-event period suggests that the reduction in tick size [for stocks traded on the American Stock Exchange] does not generate additional volume, nor does it affect market depth. ... Because there is no significant increase in trading volume generated by the smaller tick, the reduction in the effective spread following the new tick-size rule implies that there is a wealth transfer from market makers to investors."); Jeffrey M. Bacidore, The Impact of Decimalization on Market Quality: An Empirical Investigation of the Toronto Stock Exchange, 6 J. FIN. INTERMEDIATION 92, 115 (1997) ("It is interesting that liquidity-provider profits declined following decimalization [and a corresponding tick size decrease for stocks traded on the Toronto Stock Exchange], but that market quality does not appear to have been adversely affected in other respects. ... These results are consistent with the assertion that, prior to decimalization, liquidity providers were earning rents and that the move to decimalization reduced these rents.").

40. See V. Ravi Anshuman \& Avner Kalay, Market Making with Discrete Prices, 11 REV. FIN. STUD. 81, 82 (1998).

41. One commentator expressed doubts that "[d]ecimalization will result in reduced profits for market makers [because] [n] arrower spreads will also result in lower trading costs for market makers; lower costs, in turn, should result in increased trading volumes." Junius W. Peake, Brother, Can You Spare a Dime? Let's Decimalize the U.S. Equity Markets!, in Global Equity Markets: Technological, Competitive, and Regulatory Challenges 302, 324 (Robert A. Schwartz ed., 1995).

42. See infra Section I.C. Another important factor operating in the same direction was the SEC's adoption of Regulation ATS, which "integrate[d] the growing number of alternative trading systems into the national market system." Regulation of Exchanges and Alternative Trading Systems, Exchange Act Release No. 40,760, 63 Fed. Reg. 70,844, 70,844 (Dec. 8, 1998) (codified at 17 C.F.R. 242). See House Hearing on Competition in the New Electronic Market, supra note 14, at 115 (prepared testimony of Kenneth A. Kamen, Executive Vice President, Princeton Securities Corporation) ("Because ECNs were created to facilitate matching investor orders, ECNs are not reliable liquidity providers. Rather, ECNs are most efficient for the highly capitalized markets where there are large numbers of both buyers and sellers. As a result, Regulation ATS effectively discourages small broker-dealers from providing market liquidity."); WEILD \& KIM, supra note 1, at 21 ("[As an unintended consequence of Regulation ATS] [t]he [electronic communication networks] and dark pool market exploded with new entrants, putting immense additional pressure [on] spreads [and dealer] firm economics."). 
.. With the advent of the one-penny [minimum price variation] . . . we and our competitors are providing enhanced liquidity in many fewer instances. . . . . Automatic executions and guaranteed liquidity are decreasing as liquidity providers become less proactive. ${ }^{43}$

Similarly, another consequence of smaller tick sizes was the greater feasibility of various short-term "predatory" trading activities adverse to market makers that made it "easier for a small informational advantage by the well-informed trader to become a costly disadvantage to the lessinformed market-maker." ${ }^{44}$ Furthermore,

the market-maker is very likely to be exposed to adverse price movements. For instance, if many investors are seeking to buy, the market will tend to go up, but market-makers will tend to be short, since they have taken the other side of the investors' trades. ... [I]n most cases, [a penny tick size] is not a large enough spread to defray [this] cost ....

In addition, as articulated by an executive of a leading securities exchange in the context of smaller-cap stocks, "While narrower spreads are generally a positive result for investors, especially in more liquid securities, we believe a $\$ 0.01$ minimum tick size for low-cap stocks may counterintuitively create a disincentive to provide liquidity at the best price, resulting in smaller quoted sizes and thinner markets." ${ }^{" 46}$ Others emphasized the perceived adverse impact of decimalization on institutional trading: "Since penny spreads were implemented, the average trade size has been significantly reduced, making it more difficult for funds to trade large blocks of securities, particularly in small-cap and less liquid stocks."

A related trend attributed to decimalization is the shifting focus of

43. The Implementation and Future of Decimalized Markets: Hearing Before the Subcomm. on Sec. \& Inv. of the S. Comm. on Banking, Hous., \& Urban Affairs, 107th Cong. 38-39 (2002) [hereinafter Senate Hearing on Decimalized Markets] (prepared testimony of Kenneth D. Pasternak, Chairman and Chief Executive Officer, Knight Trading Group, Inc.).

44. Michael Durbin, All About High-Frequency Trading 94 (2010).

45. Letter from Manoj Narang, Chief Exec. Officer, Tradeworx, Inc., to Elizabeth M. Murphy, Sec'y, U.S. Sec. \& Exch. Comm'n app. at 8 (Apr. 21, 2010), available at http://www.sec.gov/comments/s7-02-10/s70210-129.pdf.

46. House Hearing on Market Structure, supra note 16, at 134 (prepared testimony of Duncan Niederauer, Chief Executive Officer, NYSE Euronext).

47. Id. at 76 (prepared testimony of Kevin Cronin, Global Head of Equity Trading, Invesco, on behalf of the Investment Company Institute); see also Senate Hearing on Decimalized Markets, supra note 43, at 36 (prepared testimony of Catherine R. Kinney, Group Executive Vice President, New York Stock Exchange) ("Decimal trading has had a number of detrimental impacts on mutual funds, pension funds and other institutional investors, who act on behalf of individual investors.... This decrease in the [minimum price variation] has lowered the transparency of the market and thus made it harder for institutional investors to find the right price for the liquidity they require.”). 
securities firms from principal to agency trading, at least for some securities and for a certain period of time. This shift reflects the growing unwillingness to commit capital. ${ }^{48}$ Overall, many securities industry professionals are of the view that decimalization has had a disproportionately adverse effect on the level of liquidity of smaller-cap stocks. $^{49}$ These developments likely have decreased the attractiveness of going public for smaller companies.

Conversely, decimalization could have benefitted market makers in some ways. In fact, during the early stages of decimalization, regulators feared that "it could be less costly for specialists, market makers, and possibly certain other market participants to profit from their knowledge of limit order flow by trading ahead of limit orders for only a penny a share." ${ }^{50}$ Going even further, a securities industry professional described the impact of decimalization on NYSE specialists as a "bonanza." Importantly, exchange specialists enjoyed significant informational advantages vis-à-vis other market participants at the time, although some trading venues have since limited such advantages. ${ }^{52}$ Several representatives of the NYSE downplayed this concern, ${ }^{53}$ and empirical

48. See House Hearing on Market Structure, supra note 16, at 83-84 (prepared testimony of Joseph C. Gawronski, President and Chief Operating Officer, Rosenblatt Securities).

49. See, e.g., John D’Antona Jr., SEC To Study Tick Size for Small Caps, TRADERS MAG., May 2012, at 18, 18 ("Many of our problems with market liquidity in small and midcaps can be traced back to decimalization.... Where decimalization has helped to reduce spreads in the large-cap space, it has actually harmed liquidity.") (quoting Dennis Dick, trader, Bright Trading); Letter from Eric Hess, Gen. Counsel, Direct Edge Holdings, LLC, to Elizabeth M. Murphy, Sec'y, U.S. Sec. \& Exch. Comm'n 8 (Apr. 28, 2010), available at http://www.sec.gov/comments/s7-02-10/s70210-159.pdf ("Elements of our current market structure that potentially exacerbate the current difficult environment for small- and microcap companies include ... a [minimum price variation] that does not support the relevant return on resources invested to provide continue [sic] liquidity in these securities . ..."); see also House Hearing on Market Structure, supra note 16, at 88-89 (prepared testimony of Joseph C. Gawronski, President and Chief Operating Officer, Rosenblatt Securities) (“[I]t appears to us that the change from wide spreads and little competition among market makers to ultra-thin profit margins and intense competition has removed many of the incentives that used to exist for firms to systematically provide liquidity in small-cap names.").

50. Senate Hearing on Decimalized Markets, supra note 43, at 27 (prepared testimony of Laura S. Unger, Acting Chairman, U.S. Securities and Exchange Commission).

51. Donald E. Weeden, Weeden \& Co.: The New York Stock Exchange and the Struggle over a National Securities Market 167 (2002).

52. For instance, the NYSE eliminated the "advance 'look' at incoming orders," which previously had been available to specialists, for designated market makers as successor liquidity providers. Order Approving a Proposed Rule Change by New York Stock Exchange LLC To Create a New NYSE Market Model, Exchange Act Release No. 58,845, 73 Fed. Reg. 64,379, 64,389 (Oct. 24, 2008).

53. See Senate Hearing on Decimalized Markets, supra note 43, at 53 (prepared testimony of Robert B. Fagenson, Vice Chairman, Van der Moolen Specialist USA, LLC, and Vice Chairman, the Specialist Association of the NYSE) ("We observe that "stepping 
studies examining the immediate impact of smaller tick sizes on exchange specialists in terms of their participation rates and profits produced somewhat mixed results. ${ }^{54}$

The overall impact of decimalization on securities markets and capital formation is a multifaceted question from an empirical perspective. In the immediate aftermath of decimalization, some correctly predicted a contraction of the market making industry. ${ }^{55}$ Other conclusions about the impact of decimalization are more disputed. For instance, while a government report observed that " $[\mathrm{t}] \mathrm{he}$ willingness and ability of brokerdealers to assist companies with raising capital in U.S. markets . . does not appear to have diminished as a result of decimal pricing," ${ }^{, 56}$ the time frame and the lack of a comprehensive data set weakens this claim. A recent SEC report summarized the existing empirical studies on decimalization as showing the following major trends: effective and quoted bid-ask spreads decreased, although they did not decline for some smaller-cap stocks; the impact on institutional trading costs is uncertain; quoted depth declined, while cumulative depth did not change; trade sizes fell; the participation rate of market makers increased, while profitability of market making did

ahead' of (or 'pennying') customers almost always seems to involve trading by market professionals, including institutional traders, rather than specialists and market makers, at least in the exchange markets."); id. at 58 (responses to written questions of Senator Michael B. Enzi from Catherine R. Kinney, Group Executive Vice President, New York Stock Exchange) ("While there may be a perception that specialists are stepping ahead of customers at a minimally improved price (commonly referred to as 'pennying'), in fact a recent study shows that two-thirds of such 'one-tick-better' trades are by nonspecialists.").

54. See Tavy Ronen \& Daniel G. Weaver, 'Teenies' Anyone?, 4 J. Fin. MkTS. 231, 258 (2001) (analyzing the switch from eighths to sixteenths on the American Stock Exchange and finding that "specialist profits [were] relatively unchanged"); Robert Jennings, Getting "Pennied": The Effect of Decimalization on Traders' Willingness to Lean on the Limit Order Book at the New York Stock Exchange 9, 11 (N.Y. Stock Exch., Working Paper No. 2001-01, 2001), available at http://www.nyse.com/pdfs/pennying1.pdf (analyzing the switch to decimalized pricing on the NYSE, finding that "[ $t]$ he proportion of the one-tickbetter trades in which the specialist is the sole counter-party rises from just over one-quarter to about one-third after security prices are decimalized," and suggesting that "the floor community (i.e., specialists and floor brokers) does not take a relatively more active role in submitting pennying quotes with the smaller tick size").

55. See, e.g., Isabelle Clary, Market-Makers Get Penny-Pinched, Says Nasdaq Report, SEC. TECH. MONITOR (June 18, 2001), http://www.securitiestechnologymonitor.com/issues/20010617/964-1.html ("A one-penny [minimum price variation] will reduce spreads to the point that weaker market-makers will pull out, resulting in decreased capital commitment, which will ultimately result in a widening of spreads again to the point that market-makers have incentives to commit more capital." (quoting Gregory Smith, Analyst, J.P. Morgan Chase)).

56. U.S. Gov't Accountability Office, GAO-05-535, Securities Markets: Decimal Pricing Has Contributed to Lower Trading Costs and a More Challenging TRADING ENVIRONMENT 57 (2005). 
not fall; and incentives to promote stocks were diminished. ${ }^{57}$ Some criticism of this summary, which pointed to various limitations of the examined studies has followed. ${ }^{58}$ Furthermore, several empirical studies omitted in the SEC report concluded that less-frequently traded securities are adversely impacted by a smaller tick size, ${ }^{59}$ suggesting a possible link to capital formation. In fact, one of these studies suggested that "infrequently traded stocks [should] have a coarser price grid to promote liquidity provision. ${ }^{60}$ On the other hand, the SEC's report itself recognized the limitations of the available empirical research in connection with the capital formation process:

First . . . few studies focus on differing effects related to market capitalization. Thus, many of the findings are presented for an average firm rather than a firm of a specific market capitalization. Second, to date, the effect of decimalization on capital formation has not been explored in the literature. It is, therefore, difficult to quantify the mechanism by which, if at all, decimalization may have hindered capital formation. Third, many of these studies examine only the time period surrounding the implementation of decimalization and do not examine its longer term effects. In this regard, market structure has changed significantly since the advent of decimalization and the findings of the literature may not be as applicable today given the current and continuously evolving nature of equity markets. ${ }^{61}$

Furthermore, the report referenced the view of several representatives of the securities industry that the link between tick sizes and capital formation indeed exists. ${ }^{62}$ A securities industry group articulated such a

57. SEC StafF's Decimalization RePORT, supra note 31, at 10-11, 13, 16.

58. David Weild et al., Grant Thornton LlP, The Trouble with Small Tick Sizes: Larger Tick Sizes Will Bring Back Capital Formation, Jobs and Investor CONFIDENCE 21-24 (Sept. 2012), available at http://www.gt.com/staticfiles/GTCom/Public\%20companies\%20and\%20capital\%20markets /Trouble_Small_Ticks.pdf.

59. See Michael Aitken \& Carole Comerton-Forde, Do Reductions in Tick Sizes Influence Liquidity?, 45 ACCT. \& FIN. 171, 171-72 (2005) (analyzing transactions in stocks on the Australian Stock Exchange, a trading venue with no designated market makers, and concluding that "[s]tocks with larger relative tick sizes experience the greatest improvement in liquidity, while stocks with small relative tick sizes and low trading volume experience reduced liquidity"); Michael A. Goldstein \& Kenneth A. Kavajecz, Eighths, Sixteenths, and Market Depth: Changes in Tick Size and Liquidity Provision on the NYSE, 56 J. FIN. ECON. 125, 146 (2000) (analyzing transactions in stocks on the NYSE and concluding that, "[w]hile the cost of executing smaller orders decreased, execution costs for larger orders either did not see any benefit (for frequently traded stocks) or saw an increase in costs (for infrequently traded stocks)").

60. Goldstein \& Kavajecz, supra note 59, at 147.

61. SEC StAFF's DecimalizATION RePORT, supra note 31, at 19-20.

62. Id. at 17 n.50 (citing Letter from James Fehrenbach, Managing Dir. \& Head of 
position:

Experience has shown [that] the capital raising ability of smaller companies in initial public offerings have [sic] been negatively impacted by the unwillingness of firms to make markets in their securities in a decimal environment without [a non-penny minimum price variation]. The withdrawal of market maker sponsorship and support is directly related to the increased costs and diminished opportunities for cost recovery of illiquid securities trading without [a non-penny minimum price variation]. ${ }^{63}$

Unsurprisingly, calls to reverse the impact of decimalization by increasing tick sizes have gained substantial momentum as a result of advocacy efforts by many players in the securities industry, ${ }^{64}$ although there is, some internal skepticism as to the ultimate effectiveness of this proposal. ${ }^{65}$ As an executive of a leading securities exchange noted, "[B]y actually holding wider spreads in discrete intervals of a nickel or a dime, it could actually incentivize people to put more liquidity into the market because they will be more confident that someone won't step in front of their bid or their offer with a de minimis amount." ${ }^{\prime 66}$ Furthermore, such a step would have to be "an industrywide solution," as individual trading venues cannot act in isolation. ${ }^{67}$ Another commentator maintained that "higher tick sizes could be essential to help create more investment and quite frankly enable the recreation of firms ... f focused on supporting innovation and supporting small cap stocks from seed financings, all the

Equity Institutional Sales, and Bradford Pleimann, Managing Dir. \& Head of Equity Trading, Piper Jaffray \& Co., to Stephen M. Graham \& M. Christine Jacobs, Comm. CoChairs, SEC Advisory Comm. on Small \& Emerging Cos. (June 8, 2012), available at http://www.sec.gov/comments/265-27/26527-29.pdf; Letter from Phil Johnston, Partner \& Head of Equities, ThinkEquities LLC, to SEC Advisory Comm. on Small \& Emerging Cos. (June 8, 2012), available at http://www.sec.gov/comments/265-27/26527-28.pdf; Letter from Jeffrey Solomon, Chief Exec. Officer, Cowen \& Co., LLC, to SEC Advisory Comm. on Small \& Emerging Cos. (June 4, 2012), available at http://www.sec.gov/comments/26527/26527-27.pdf).

63. Letter from Jennifer Green Setzenfand, Chairman of the Bd., and James Toes, President \& CEO, Sec. Traders Ass'n, to Elizabeth M. Murphy, Sec'y, U.S. Sec. \& Exch. Comm'n 2 (July 16, 2012), available at http://www.sec.gov/comments/jobs-title-i/tick-sizestudy/ticksizestudy-2.pdf.

64. See WeILD ET AL., supra note 58, at 17-20.

65. See Peter Chapman, Industry Divided on Bigger Ticks for Small Stocks, TRADERS MaG. ONLINE News (Apr. 18, 2013), http://www.tradersmagazine.com/news/equitiesindustry-pros-divided-on-bigger-ticks-small-caps-111107-1.html (registration required).

66. House Hearing on Roadblocks in Public Markets, supra note 16, at 35 (remarks of Joseph Mecane, Executive Vice President and Chief Administrative Officer, U.S. Markets, NYSE Euronext).

67. Id. at 36 . 
way through to the IPO process and as small cap public companies." ${ }^{68}$ Others argued that tick sizes "greater than one penny can create benefits to the capital formation process by reducing the costs of maintaining a trading center, improving overall liquidity, both displayed and enhanced, in previously less liquid securities, and improving investor confidence in market structure." ${ }^{, 69}$

Given the current debates, a tick size pilot program is a real possibility, although its design and implementation would require some effort. $^{70}$ More generally, as noted by some commentators, factors considered in the determination of an optimal tick size should include absolute price and liquidity / trading activity. ${ }^{71}$ Furthermore, one potential complication with implementing larger tick sizes is the requirement that "[1]iquidity rebates, payment for order flow, executions within tick increments through dark pools and other mechanisms that effectively enable trading within established tick sizes should be eliminated to create tick size "integrity.",72 On a related note, several commentators from the academic and business communities have suggested authorizing issuers to choose the applicable tick size. ${ }^{73}$ Furthermore, while "the issue of bid/ask

68. Letter from Phil Johnson to SEC Advisory Comm. on Small \& Emerging Cos., supra note 62 , at 1.

69. Letter from Jennifer Green Setzenfand \& James Toes to Elizabeth M. Murphy, supra note 63 , at 3 .

70. For a discussion of possible considerations, some of which are technical in nature, see Letter from Stuart J. Kaswell, Exec. Vice President \& Managing Dir., Gen. Counsel, Managed Funds Ass'n, to Elizabeth M. Murphy, Sec'y, U.S. Sec. \& Exch. Comm'n (Apr. 23, 2013), available at http://www.sec.gov/comments/4-657/4657-20.pdf; Letter from David Weisberger, Exec. Principal, Two Sigma Sec., LLC, to Elizabeth M. Murphy, Sec'y, U.S. Sec. \& Exch. Comm'n (Apr. 23, 2013), available at http://www.sec.gov/comments/4657/4657-19.pdf.

71. See Asli Ascioglu et al., An Examination of Minimum Tick Sizes on the Tokyo Stock Exchange, 22 JAP. \& WORLD ECON. 40, 46-47 (2010); Letter from Christopher Nagy, President, KOR Trading LLC, to Elizabeth M. Murphy, Sec'y, U.S. Sec. \& Exch. Comm'n 1 (July 24, 2012), available at http://sec.gov/comments/jobs-title-i/tick-sizestudy/ticksizestudy-3.pdf.

72. WEILD ET AL., supra note 58, at 2 n.2.

73. House Hearing on Market Structure, supra note 16, at 23 (remarks of Duncan Niederauer, Chief Executive Officer, NYSE Euronext); WEILD ET AL., supra note 58, at 2; Yakov Amihud \& Haim Mendelson, A New Approach to the Regulation of Trading Across Securities Markets, 71 N.Y.U. L. REV. 1411, 1449 (1996); Letter from James J. Angel, Assoc. Professor of Fin., McDonough Sch. of Bus., Georgetown Univ., to U.S. Sec. \& Exch. Comm'n 5 (June 19, 2012), available at http://www.sec.gov/comments/jobs-title-i/tick-sizestudy/tick-size-study-1.pdf. But see Letter from Thomas M. Carter, Chairman of the Bd., and James Toes, President \& CEO, Sec. Traders Ass'n, to Elizabeth M. Murphy, Fed. Advisory Comm. Mgmt. Officer, U.S. Sec. \& Exch. Comm'n 4 (Apr. 30, 2013), http://www.sec.gov/comments/265-27/26527-37.pdf ("Providing [an] option[] [such as picking the applicable tick size] empowers [company] executives to make decisions on matters which they lack expertise in. ... [P] roviding companies with such an option on tick sizes would set a precedent for perhaps allowing other trading variables to be determined by 
spreads [dependent on the applicable tick size] is a double-edged sword that cuts emerging growth companies both ways [that impacts both] the economic infrastructure necessary for emerging growth company IPOs [and] trading volumes and valuations," 74 in some instances that liquidity might not exist in a universe with smaller tick sizes. Overall, this disagreement over the impact of tick sizes supports the argument for an issuer-picked tick size.

\section{Order Handling Rules}

The term "order handling rules" refers to a set of requirements adopted by the SEC in 1996 with respect to execution obligations. This regulatory change chiefly required dealers to display customer limit orders in addition to their own quotes and to make publicly available their quotes at superior prices on electronic communication networks. ${ }^{75}$ Several commentators, including the National Association of Securities Dealers ("NASD") and the Securities Industry Association, opposed these requirements, arguing that, if public limit orders were to be displayed, "many firms will decide not to make the necessary capital commitment to continue their market making operations [and] the decrease in liquidity will impair the capital formation process." ${ }^{, 6}$ In its turn, the SEC flatly rejected the position that "there will be a significant negative impact [as] customer orders are the ultimate source of liquidity to the markets [and] a rule that improves the handling of such orders will have the effect of enhancing market liquidity." 77 Without too much scrutiny, the regulatory agency also dismissed the concern of "the availability of liquidity to small issuers" by

issuers. For example, should an issuer's shares trade in a regime which does not allow maker/taker practices or only on particular exchanges. [sic]"). Interestingly, a bill recently introduced in the U.S. Congress, Spread Pricing Liquidity Act of 2013, H.R. 1952, 113th Cong. (2013), would allow issuers to have more control over the applicable tick size. See also Press Release, Biotechnology Indus. Org., BIO Applauds Rep. David Schweikert for Introducing Spread Pricing Liquidity Act (May 15, 2013), http://www.bio.org/media/pressrelease/bio-applauds-rep-david-schweikert-introducing-spread-pricing-liquidity-act

(expressing its support for the bill and describing it as "designed to increase liquidity and spur capital formation for small businesses, including emerging biotech companies that are traded on the public market").

74. Timothy J. Keating, Keating Invs., LLC, The JOBS Act: Shifting into Gear and Accelerating up the IPO On-Ramp 10 (May 2012) (unpublished manuscript) (on file with author), available at http://keatingcapital.com/wp-content/uploads/2012/05/The-JOBS-ActShifting-into-Gear-and-Accelerating-Up-the-IPO-On-Ramp-May-2012.pdf.

75. Order Execution Obligations, Exchange Act Release No. 37,619A, 61 Fed. Reg. 48,290 (Sept. 6, 1996).

76. Id. at 48,299. The same argument was made with respect to the proposed requirement for dealers to make publicly available their quotes at superior prices placed through electronic communication networks. Id. at 48,290, 48,300 n.121.

77. Id. at 48,299 . 
stating that "there is no convincing evidence that Nasdaq issuers, including IPO issuers, are dependent for liquidity on any one market maker.,"78

While liquidity provided by public limit orders may complement liquidity provided by dealers as a group, dealers may effectively be supplanted - with potentially adverse consequences for the overall level and stability of liquidity. Theoretically, allowing a direct interaction of public limit orders could change the structure of bid-ask spreads:

The spread between ask and bid prices that emerges from the reservation prices contained in investor limit orders . . does not have a cost-based minimum like that which should set a floor to the spread emanating from the reservation prices of specialists and market makers when trading for their own accounts. Rather, the spread set via investor limit orders has a theoretical minimum that is only epsilon greater than zero; the actual spreads are determined by the degree of difference in judgments about a stock's value (i.e., of its future performance), and this difference can be quite small in a particular case. ${ }^{79}$

Taking this point even further, the business model of dealer-provided liquidity as such may be strained: "Dealers will not narrow their spreads to the point that they cannot profit from trading. Public limit order traders, however, may narrow spreads beyond this point [as they] want to execute their trades [and hence] may place their orders very close to the market." 80

There has been some empirical research on the impact of the order handling rules. For instance, one early study of NASDAQ found smaller bid-ask spreads and "sufficient depth at the posted quotes ... suggest[ing] that an investor's round-trip transactions cost has unambiguously fallen under the new rules." ${ }^{\text {" } 1 ~}$ Another study argued that NASDAQ spreads decreased due to the cumulative effect of the order handling rules and a pre-decimalization tick size change from eighths to sixteenths. ${ }^{82}$ Yet another study similarly analyzed the cumulative effect of the order handling rules and the switch from eighths to sixteenths around the adoption of these measures, concluding that "[t]hinly-traded stocks have not experienced much of a spread decline" ${ }^{\not, 3}$ and documenting only a slight

78. Id. at 48,300 .

79. Harold Demsetz, Limit Orders and the Alleged Nasdaq Collusion, 45 J. Fin. Econ. 91, 93 (1997). The same commentator also noted that" [w]ith recycling of revenue inventory reduced or eliminated, market makers, if they are to remain in business, will require procedural changes that result in new sources of revenue." Id. at 94.

80. Harris, supra note 37 , at 4.

81. Michael J. Barclay et al., Effects of Market Reform on the Trading Costs and Depths of Nasdaq Stocks, 54 J. FIN. 1, 32 (1999).

82. Kee H. Chung \& Chairat Chuwonganant, Tick Size, Order Handling Rules, and Trading Costs, Fin. MGMT., Spring 2004, at 47.

83. Jeffrey W. Smith, The Effects of Order Handling Rules and 16ths on Nasdaq: A 
decrease in the number of active stocks. ${ }^{84}$ On the other hand, there is some evidence that several full-service securities firms had substantially cut the number of NASDAQ stocks they were making markets in as a result of this regulatory development. ${ }^{85}$ However, the problem with the existing research, just as in the case of the impact of decimalization, is the lack of emphasis on long-term developments and the spillover to the capital formation process.

Oftentimes, the adoption of the order handing rules has been questioned or openly condemned. An investment banking executive argued that "the SEC did not study how the proposed Order Handling Rules would affect the liquidity and volatility of small cap stocks. In hindsight this omission was a critical error." ${ }^{" 86}$ Other commentators observe that, while the order handling rules "clearly were intended to increase transparency and create an even playing field for retail investors ... . [the] impact, unforeseen as it may have been, was devastating. Stock spreads narrowed, and the economics to broker-dealers continued to erode." Another criticism is that the order handling rules "reduce[d] the financial incentives available to broker-dealers to market Nasdaq stocks." 88 Unsurprisingly, there are calls for a reversal of key features of the order handling rules. Indeed, a venture capitalist urged "[e]liminat[ing] electronic execution that bypasses market makers, restoring a positive market spread so that liquidity providers are paid to risk their capital." ${ }^{89}$

Cross-Sectional Analysis 17 (Nat'l Ass'n of Sec. Dealers, Working Paper No. 98-02, 1998).

84. Id. at 7.

85. Mark Ingebretsen, NASDAQ: A History of the Market That Changed the WORLD 151-52 (2002).

86. House Hearing on Competition in the New Electronic Market, supra note 14, at 114 (testimony of Kenneth A. Kamen, Executive Vice President, Princeton Securities Corporation, and Chairman of the Board of Directors, Regional Investment Bankers Association).

87. WeILD \& KIM, supra note 1, at 13. On a related note, the impact of the order handling rules was even questioned by Arthur Levitt, the former SEC Chairman: "The irony of all this is that the change in order handling rules that were instituted under my watch at the Commission has resulted in the proliferation of markets, technologies and automation that brought about the Flash Crash [of May 6, 2010] and [the Knightmare on Wall Street of August 1, 2012]." Levitt Says Market Glitches Shake Public Confidence, BloomberG RADIO (Aug. 2, 2012), http://media.bloomberg.com/bb/avfile/News/Surveillance/vpvDY1zpP4Fo.mp3.

88. Reena Aggarwal \& James J. Angel, Optimal Listing Policy: Why Microsoft and Intel Do Not List on the NYSE 29 (Apr. 1998) (unpublished manuscript) (on file with author), available http://www.underpricing.de/Downloads/Aggarwal_Optimal\%20Listing.pdf.

89. Pascal N. Levensohn, Levensohn Venture Partners, Keynote Remarks Before REFF-West $21 \quad$ (Sept. 30, 2009), http://www.levp.com/catbin/filexfer/show/093009REFFWestSlideswithNotes.pdf?artist_id=365\&folder=news_attac hments\&file=093009REFFWestSlideswithNotes.pdf. 


\section{Blurring Boundaries Between Auction and Dealer Markets}

The adoption of the order handling rules is just one manifestation of the convergence of auction and dealer markets, which in the past were respectively exemplified by (i) the NYSE functioning as a consolidated book of limit and market orders that matched buyers and sellers with a single specialist acting as an order-matching agent and a dealer and (ii) NASDAQ functioning as a network of competing dealers posting quotes and often playing other roles as multifunctional securities firms, such as underwriting, securities research, and brokerage services. ${ }^{90}$ While there could be a discussion of differences between the NYSE and NASDAQ in terms of total market making capital available and diversification of risk, ${ }^{91}$ these differences are not-and were not-set in stone. Furthermore, competitive dynamics of these two markets were not necessarily very different. As an empirical study of NASDAQ concluded, "[T] he fiction of atomistic dealer markets is just that; for most stocks [in the sample], there is a dominant liquidity provider, much as would be the case in a specialist market." ${ }^{92}$ Perhaps a more pivotal distinction is that "[a] dealer[] market

90. For instance, one study of NASDAQ noted that "market making is typically bundled with brokerage, analyst coverage and underwriting in the same firm." Paul Schultz, Who Makes Markets?, 6 J. FIN. MKTS. 49, 72 (2003). A leading NASDAQ market maker similarly remarked that the "sponsorship function of market makers is a synergetic package [that includes] [h] eightening the visibility of NASDAQ stocks . . by publicizing the stocks through careful and frequent research reports [and] [c]alling worldwide attention to NASDAQ stocks through an army of securities salesmen." John N. Tognino, Market-Maker Sponsorship: A Synergetic Package of Services, in THE NASDAQ HANDBOOK: THE STOck MARKET OF TOMORROW-TODAY 301, 301 (Douglas F. Parrillo et al. eds., 1987) [hereinafter THE NASDAQ HANDBOOK].

However, even NYSE specialist firms ultimately evolved from smaller focused firms to integral parts of large multifunctional securities firms with varying degrees of diversification. This evolution was accompanied by the relaxation of regulatory barriers for engaging in different interrelated activities. Taking a major step in that direction in 1986, the NYSE lifted the prior restrictions on entities affiliated with specialist firms with respect to "accepting orders in specialty securities from institutions, the issuer, and its insiders," "performing research and advisory services with respect to specialty securities," "“popularising' specialty securities," and "engaging in business transactions with [the issuer]," conditional on the adoption of Chinese Walls. Order Approving Proposed Rule Changes by New York Stock Exchange, Inc. and American Stock Exchange, Inc. To Amend the Exchanges' Rules Relating to Approved Persons of Specialists, Exchange Act Release No. 23,768, 51 Fed. Reg. 41,183, 41,183-84 (Nov. 3, 1986). The restriction on being affiliated with a lead underwriter of relevant securities specifically retained by the NYSE in 1986, id. at 41,184, was suspended and then permanently abolished soon thereafter. See Order Approving a Proposed Rule Change by New York Stock Exchange, Inc., Exchange Act Release No. 26,125, 53 Fed. Reg. 39,395, 39,395-96 (Sept. 28, 1988).

91. See, e.g., John C. Groth \& David A. Dubofsky, The Liquidity Factor, in THE NASDAQ HANDBOOK, supra note 90, at 361, 367; James H. Lorie, Economic Efficiency and NASDAQ, in THE NASDAQ HANDBOOK, supra note 90, at 347, 353.

92. Katrina Ellis et al., The Making of a Dealer Market: From Entry to Equilibrium in 
typically does not provide facilities for ordinary traders to expose their limit orders, so that it is impracticable and costly to bypass the market makers [and thus] traders always pay the bid-ask spread even if a matching order is available." $" 93$

The choice between auction and dealer markets - a simplified distinction between the prestige and visibility of the former and the availability of additional services of the latter-may have a significant impact on smaller-cap companies. For instance, one study pointed out that, "[f]or some companies, the added benefits of increased exposure via the Nasdaq system may provide lower capital costs despite higher transaction costs." ${ }^{\text {9 }}$ A European industry group similarly pointed to the advantages of the NASDAQ-like architecture with respect to capital formation and liquidity:

Nearly every IPO practitioner that we interviewed agreed that a market making trading system, similar to that of NASDAQ, creates increased liquidity for small cap stocks. . . . [S]tock exchanges [should] take a proactive role in promoting market making platforms by creating incentives for brokerage firms to risk capital in this activity. ${ }^{95}$

Historically, it was recognized that transferring securities from a dealer market to an auction market, i.e., from the pre-NASDAQ over-the-counter market to a securities exchange, could decrease liquidity in terms of "their activity and marketability" because of the lack of dealer capital commitment and, as a more idiosyncratic reason for that time period, a more rigid brokerage commission structure. $^{96}$ From an empirical perspective, one study analyzed the introduction of a quote-driven trading mechanism administered by registered market makers to replace a limit order book for the Japanese equivalent of NASDAQ, a trading venue for

the Trading of Nasdaq Stocks, 57 J. Fin. 2289, 2291 (2002). Furthermore, the same study maintained that "free entry does little to improve the competitive nature of the market, as entering dealers have little impact." Id.

93. Marco Pagano \& Ailsa Röell, Auction and Dealership Markets: What Is the Difference?, 36 EuR. ECON. REV. 613, 620 (1992).

94. Aggarwal \& Angel, supra note 88 , at 16.

95. High Tech Comm., Eur. Private Equity \& Venture Capital Ass'N, Fulfilling the Promise of Venture-Backed High Potential Companies: Why We Need To Fix SMALL CAP MARKETS IN EUROPE 4 (Oct. 2005), available at $\mathrm{http} / / /$ www.evca.eu/uploadedFiles/fulfilling_promise_venture-backed_companies.pdf [hereinafter EVCA, Why We NeEd To Fix SMall CAP Markets in Europe].

96. Jacob O. Kamm, The Decentralization of Securities Exchanges 81 (1942); see also id. at 88 ("A point often stressed in hearings in which corporations apply for delisting of their securities from trading on an exchange is that the securities would enjoy a more active market if they were traded over-the-counter."). Yet another historic reason for the attractiveness of over-the-counter markets was the greater regulatory burden on issuers of exchange-traded securities. $I d$. at 89 . 
smaller-cap stocks, and identified improvements in liquidity. ${ }^{97}$ Another study that analyzed the introduction of a limit order book on the Riga Stock Exchange found that this feature had a harmful effect on less liquid stocks in terms of trading volume, concluding that "an auction system [has] no benefits to be reaped by small-capitalization stocks as the loss of a market maker can not [sic] be entirely compensated by reduced trading costs and technological innovations." 98 A similar study examined the impact of "the introduction of the limit order book and the removal of the market makers' obligations" on "a group of moderately liquid stocks" on the London Stock Exchange, finding that "the liquidity of those stocks dropped substantially." The corresponding policy implication was that "a hybrid market with a limit order book and voluntary dealers may not perform as well as a dealership market with obligatory market makers."

Furthermore, there have been numerous empirical studies dealing with transaction costs in auction and dealer markets - once again exemplified by the NYSE and NASDAQ - given their different institutional features. ${ }^{101}$ Specifically with respect to firm size, one empirical study suggested that, "[a]mong [comparable] smaller capitalization stocks, the NASDAQ apparently provides liquidity at a lower cost than the NYSE."102 By contrast, another study concluded that "[bid-ask] spreads for the majority of medium and small capitalization stocks remain narrower on the NYSE [after decimalization]." ${ }^{\prime 103}$ Interestingly, one study analyzing options trading, in which the integrated model of market making is of less relevance, noted that, "[w]hen trading volume is low, the specialist structure is associated with significantly smaller spreads." ${ }^{104}$ In any

97. Philip Y.K. Cheng \& Martin Young, An Analysis of the Impact of the Introduction of Market Makers to the Japan Securities Dealers Association Quotations (JASDAQ) Market (2002) (unpublished manuscript) (on file with author).

98. Joseph P. Kairys Jr. et al., Winners and Losers from the Introduction of Continuous Variable Price Trading: Evidence from the Riga Stock Exchange, 24 J. BANKING \& Fin. 603, 603, 609-10, 620 (2000).

99. Hung-Neng Lai, The Market Quality of Dealer Versus Hybrid Markets: The Case of Moderately Liquid Securities, 34 J. Bus. Fin. \& AcCT. 349, 349 (2007).

100. Id.

101. See, e.g., John Affleck-Graves et al., Trading Mechanisms and the Components of the Bid-Ask Spread, 49 J. FIn. 1471 (1994); Hendrik Bessembinder \& Herbert M. Kaufman, A Comparison of Trade Execution Costs for NYSE- and NASDAQ-Listed Stocks, 32 J. FIN. \& Quant. Analysis 287 (1997); Roger D. Huang \& Hans R. Stoll, Dealer Versus Auction Markets: A Paired Comparison of Execution Costs on NASDAQ and the NYSE, 41 J. FIN. ECON. 313 (1996).

102. Marc R. Reinganum, Market Microstructure and Asset Pricing: An Empirical Investigation of NYSE and NASDAQ Securities, 28 J. FIN. ECON. 127, 135 (1990).

103. Hendrik Bessembinder, Trade Execution Costs and Market Quality After Decimalization, 38 J. Fin. \& QuANT. ANALYsis 747, 750 (2003).

104. Robert Neal, A Comparison of Transaction Costs Between Competitive Market Maker and Specialist Market Structures, 65 J. Bus. 317, 317 (1992). 
instance, there is a balance between the cost of additional services recouped by a market maker via higher transaction costs and the marginal liquidity generated by these additional services that potentially pushes down transaction costs.

The continuing convergence of dealer and auction markets, the process in which the SEC has played an important role, predates the adoption of the order handling rules in $1996 .{ }^{105}$ As a securities industry professional forcefully argued, "The [SEC] has dealerized the auction market, auctionized the dealer market [and] turned both of them into electronic ECNs." 106 The evolution of NASDAQ was also influenced by the scandal triggered by the alleged collusion of dealers to keep bid-ask spreads artificially large and other related practices, ${ }^{107}$ and some commentators are still questioning the rationale behind and the overall impact of this government intervention. ${ }^{108}$ Auction markets have also taken

105. See The Regulatory Threat to NASDAQ: A Lexecon Report 14-15 (Jan. 1995), available http://c0403731.cdn.cloudfiles.rackspacecloud.com/collection/papers/1990/1995_0101_Nas daqLexecon.pdf (describing several contemporary initiatives of NASDAQ, such as the implementation of a rule giving priority to limit orders placed by dealers' own customers and the proposal to create a centralized limit order book for small orders, and arguing that these initiatives, "which were themselves adopted under strong SEC pressure, already represent a substantial abandonment of the highly successful dealer market concept").

106. Letter from Steve Wunsch, Wunsch Auction Assocs., LLC, to Elizabeth M. Murphy, Sec'y, U.S. Sec. \& Exch. Comm'n 14 (Jan. 14, 2010), available at http://www.sec.gov/comments/s7-27-09/s72709-32.pdf.

107. For background information relating to this controversy, see In re NASDAQ Market-Makers Antitrust Litig., 169 F.R.D. 493 (S.D.N.Y. 1996); United States v. Alex. Brown \& Sons Inc., No. 96 CIV. 5313, 1996 U.S. Dist. LEXIS 22952 (S.D.N.Y. July 26, 1996); Certain Market Making Activities on NASDAQ, Exchange Act Release No. 40,900, 68 SEC Docket 2693 (Jan. 11, 1999); Report Pursuant to Section 21(a) of the Securities Exchange Act of 1934 Regarding the NASD and the NASDAQ Market, Exchange Act Release No. 37,542, 52 S.E.C. 882 (Aug. 8, 1996).

108. See, e.g., WEILD \& KIM, supra note 1, at 21 (arguing that, while the goal of the government agencies was to "[e]liminate tacit collusion among market makers and reduce trading costs for investors", these measures "[b]egan cutting into economic incentive for market-making firms to provide liquidity and support of stocks"); Steve Wunsch, Straitjacket, Part 2: The Role of Stop-Loss Orders and Stub Quotes on May 6, TABB ForUM (Jan. 31, 2011), http://tabbforum.com/opinions/straitjacket-part-2-stop-loss-orders-and-stubquotes (registration required) (arguing that the government agencies "seemed scandalized by this practice, as if it were manipulative and deceptive, rather than just a normal practice that recognized the reality of dealers' one-sided interest"); see also Gerald T. Garvey \& Michael S. McCorry, Multidimensional Competition on NASDAQ: Did Traders Gain When Dealers Stopped Avoiding Odd-Eighth Quotes? 3 (Oct. 1996) (unpublished manuscript) (on file with author), available

http://citeseerx.ist.psu.edu/viewdoc/download?doi=10.1.1.203.2122\&rep=rep1\&type=pdf (providing an empirical analysis of these changes and concluding that "investors did gain when dealers introduced odd-eighth quotes, but that this gain was substantially muted by a reduction in other dimensions of transaction quality and service"). 
several steps towards convergence. For instance, market making was "deagentized" in the sense that specialists with both dealer and agent functions are being replaced by multiple dealer-only market makers. ${ }^{109}$ Yet, overall, the changes in dealer markets are more important-if not game-changing - from the standpoint of the capital formation process, and the business model of market makers operating in such markets has been threatened by this process of convergence.

\section{E. Cross-Subsidization of Market Making in Different Securities}

With respect to the NYSE and perhaps several other exchanges, another factor that contributed to enhanced liquidity of smaller-cap stocks - with some correlation to emerging companies despite the NYSE's bias toward mature ones-was its policy of allocating securities among specialist firms that seemed to encourage cross-subsidization between different types of stocks. The "olden days" leadership of the NYSE in fact indicated that

specialists, who were earning excess profits on larger capitalization stocks that were inherently liquid, [were caused] to reinvest a share of those profits to shore up liquidity in smaller capitalization stocks. This so-called allocation system, as a matter of public policy, recognized that smaller capitalization stocks needed investments made to drive liquidity. ${ }^{110}$

This policy appears to have been informal and loosely defined, although occasionally hinted at, ${ }^{111}$ and it probably came under the umbrella of the

109. See Dolgopolov, supra note 12, at 343 \& nn.212-13.

110. David Weild \& Edward Kim, Killing the Stock Market That Laid the Golden Eggs, in SAl L. Arnuk \& Joseph C. SAluzzi, Broken Markets: How High Frequency Trading and Predatory Practices on Wall Street Are Destroying Investor Confidence and Your PoRTFOLIO 195, 209-10 (2012) (describing the views of Richard Grasso, the former Chairman and CEO of the NYSE, and Richard Bernard, the former General Counsel of the NYSE); see also Computerized Trading: What Should the Rules of the Road Be? - Part I: Hearing Before the Subcomm. on Sec., Ins., \& Inv. of the S. Comm. on Banking, Hous., \& Urban Affairs, 112th Cong. 56 (2013) [hereinafter Senate Hearings on Computerized Trading - Part I] (prepared testimony of Larry Tabb, CEO, TABB Group) ("Historically, when the exchanges had more control of which firms had the best trading economics, the exchanges forced these firms (which were market makers) to cover both more- and lessliquid stocks. They tended to make money on the more-liquid stocks, break even on stocks with a moderate amount of liquidity, and they lost money on less-liquid stocks (no matter how wide the spread).").

111. See, e.g., N.Y. Stock Exch., Economic EfFects of Negotiated Commission Rates on the Brokerage Industry, the Market for Corporate SECurities, and the INVESTING PUBLIC 24 (Aug. 1968) (linking the ability of specialists "to make effective markets in normally inactive stocks" and "the financial incentive arising from marketmaking in more active issues"). 
NYSE's formal goal of "spread[ing] reward and risk throughout the specialist system, in order to contribute to its strength and continued viability." Furthermore, there are economic justifications behind this policy's existence. ${ }^{113}$ Several empirical studies also point to the existence of such cross-subsidization on the NYSE in the past. ${ }^{114}$ Empirical research finding that the NYSE had wider effective bid-ask spreads for larger-cap stocks and narrower bid-ask spreads for smaller-cap stocks compared to NASDAQ after decimalization but before Reg $\mathrm{NMS}^{115}$ is also consistent

112. N.Y. Stock Exch., Inc., Information Memo No. 95-33, 1995 NYSE Info. Memo LEXIS 31 Exh. A, at *4-5 (Aug. 3, 1995); see also Shane A. Corwin, Specialist Performance and New Listing Allocations on the NYSE: An Empirical Analysis, 7 J. FIN. MKTs. 27, 28, 32 (2004) (analyzing transactions in stocks from 1992 to 1998 and "find[ing] that more-profitable and less-profitable listings tend to be equitably distributed across specialist firms [which is] consistent with the objective to spread reward and risk across specialist firms").

113. See Charles Cao et al., Does the Specialist Matter? Differential Execution Costs and Intersecurity Subsidization on the New York Stock Exchange, 52 J. FIN. 1615, 1638 (1997) (theorizing that "cross-subsidization may build future demand for liquidity in the low volume stocks [and] low trading stocks for smaller firms may attract more new listings to the NYSE by demonstrating that the costs for investors wishing to trade their securities will be low"); Roger D. Huang \& Jerry W. Liu, Do Individual NYSE Specialists CrossSubsidize Illiquid Stocks? 32 (Nov. 2003) (unpublished manuscript) (on file with author) (noting that cross-subsidization "is compatible with the exchange's motive to provide liquidity for all stocks, including inactive stocks" and theorizing that it "increases the number of stocks for which NYSE listing is feasible [and thus] increase[s] overall market liquidity").

114. See, e.g., Cao et al., supra note 113, at 1616, 1620 (analyzing transactions in stocks in 1993 and concluding that "[t]he evidence is consistent with the existence of a crosssubsidy from actively traded stocks to inactively traded stocks within a specialist firm"); Bülent Köksal, Differences in Individual NYSE Specialists' Performances and Strategies, 19 REV. Fin. ECON. 8, 10, 14 (2010) (analyzing transactions in stocks in 2001 and concluding that "[o]ur results provide evidence that the individual specialists subsidize inactive stocks by increasing order processing cost component of the bid-ask spread for more active stocks in their portfolios"); Huang \& Liu, supra note 113, at ii, 2 (analyzing transactions in stocks in 1998 and concluding that "[t]he existence of cross-subsidization is confirmed by tests from the perspectives of both donor and beneficiary stocks within the same portfolio ... document[ing] support for illiquid stocks in a specialist market"). Compare JOEL Seligman, The Transformation of Wall Street: A History of the Securities and EXCHANGE COMMISSION AND MOdERn CORPORATE FinANCE 339 n.* (analyzing transactions in stocks in 1974 and concluding that "it [could not] be persuasively argued that specialists needed high dealer profits in actively traded securities to subsidize dealer losses in less actively traded securities [because] when both specialist agency and dealing income were taken into account, specialists earned money on their trading activities on all common stocks"), with George Sofianos, Specialist Gross Trading Revenues at the New York Stock Exchange 16 (N.Y. Stock Exch., Working Paper No. 95-01, 1995) (analyzing transactions in stocks in 1993, finding that "specialists on average make zero trading revenues on 70 percent of the stocks in the sample," and pointing out that "there is no evidence that the specialist [sic] make statistically significant losses in any of these trading volume deciles").

115. Robert J. Shapiro, Pac. Research Inst., Costs for Investors of Trading on the NYSE and NASDAQ: A Floor-Based, Specialist Auction Market, Versus an Open Access, 
with the cross-subsidization hypothesis, although this result might be attributed to other NYSE-NASDAQ institutional differences. ${ }^{116}$ Of course, this feature of cross-subsidization has been fading away, given the requirement of above-normal profits on providing liquidity in activelytraded securities, ${ }^{117}$ as the fragmentation of the overall volume of transactions across trading venues and intermarket linkages preclude this scenario. ${ }^{118}$

Computer-Based Network (Nov. 2004) (unpublished manuscript) (on file with author), available at http://www.pacificresearch.org/docLib/2004_Market_Briefing.pdf; see also id. at 4 ("[T] he data show that the NYSE specialists' guarantee to fill every order is best suited to small companies where buyers or sellers may be relatively scarce, while NASDAQ's competitive network better ensures maximum liquidity for other firms.").

116. The overall ambiguity of this issue is illustrated by a similar empirical study that compared quoted bid-ask spreads on the NYSE and NASDAQ around decimalization but before Reg NMS. Bessembinder, supra note 103. This study found that these NASDAQ had wider spreads for large-cap stocks and statistically indistinguishable spreads for medium-cap and small-cap stocks during a sample period amounting to less than a month before decimalization, and the NYSE still had larger spreads for large-cap stocks-but narrow spreads for medium-cap and small-cap stocks-post-decimalization. Id. at 755 tbl.1.

117. See William O. Brown, Jr. et al., Competing with the New York Stock Exchange, 123 Q.J. ECON. 1679, 1679 (2008) (presenting empirical evidence consistent with the view that the NYSE specialists possessed market power to charge higher bid-ask spreads in the past); Harold Demsetz, The Cost of Transacting, 82 Q.J. ECON. 33, $42-45$ (1968) (analyzing sources of market power and competitive forces in the context of the specialist system on the NYSE); Nan S. Ellis et al., The NYSE Response to Specialist Misconduct: An Example of the Failure of Self-Regulation, 7 BERKELEY BuS. L.J. 102, 114 \& nn.82-83, 136 \& nn.23233 (2010) (discussing high profitability of NYSE specialists in the past); Brian C. Becker, Profitability Analysis of NYSE Trading Specialists 1 (Feb. 2004) (unpublished manuscript) (on file with author) (concluding that "NYSE trading specialists earn very high operating levels of profitability [and] [t]heir operating profit margins were consistently higher than those earned by firms in similar industries as well as a broad cross section of other industries"). An interesting historical debate relates to the source of profits of NYSE specialists. Compare Joel Hasbrouck \& George Sofianos, The Trades of Market Makers: An Empirical Analysis of NYSE Specialists, 48 J. FiN. 1565, 1569, 1576, 1588 (1993) (analyzing transactions in stocks from 1988 to 1991 and arguing that NYSE specialists' "profits are almost entirely a consequence of the bid-ask spread"), with Sigridur Benediktsdottir, An Empirical Analysis of Specialist Trading Behavior at the New York Stock Exchange 4, 6 (Fed. Reserve Sys., Int'1 Fin. Paper Discussion No. 876), available at http://www.federalreserve.gov/pubs/ifdp/2006/876/ifdp876.pdf (analyzing transactions in stocks from 1990 to 1991 and concluding that "[NYSE] specialists receive compensation from profitable self-initiated trading rather than just from the bid-ask spread [and] [d] espite the fact that liquidity trades by definition include spread profit, the overall profit from specialist-initiated trades is higher").

118. For instance, a startling statistic is that the share of transactions in NYSE-listed securities executed on the NYSE itself dropped from $79.1 \%$ in 2005 to $25.1 \%$ in 2009 . See Concept Release on Equity Market Structure, Exchange Act Release No. 61,358, 75 Fed. Reg. 3594, 3595 fig.1 (Jan. 14, 2010). For a more general discussion of the impact of competition on cross-subsidizing practices in the securities industry, see Ian Domowitz \& Benn Steil, Automation, Trading Costs, and the Structure of the Securities Trading Industry, in Brookings-Wharton Papers on Financial Services: 1999, at 33, 46-50 (Robert E. 


\section{F. Other Functions Performed by Market Makers}

The evolution of securities markets should also be viewed through the lens of the integrated model of market making in order to analyze diminished incentives to provide liquidity. For instance, it appears that large tick sizes, in addition to being a subsidy for market making as such, were also subsidizing analyst coverage as an essential part of the capital formation process. Other forces working in the same direction similarly put a strain on the integrated model and, as a result, hampered emerging companies. As one securities industry professional remarked in support of this argument,

[D]ecimalization had put the economic sustainability of sell-side research departments under stress by reducing the spreads and trading commissions that formerly helped to fund research analyst coverage. The Global Analyst Settlement of 2003 increased that stress by prohibiting the direct compensation of research analysts through investment banking revenue. This limited the compensation sources for analysts to trading revenues. As a result, most sell-side research analysts have shifted their attention to the high-volume, high-liquidity largecap stocks that now drive revenues for their institutions and provide the basis for their compensation. This shift has resulted in less research coverage of emerging growth companies and thus less transparency and visibility into emerging growth companies for investors - an outcome that contradicts the original intent of the regulations in question. ${ }^{119}$

This point of view has also been articulated by another securities industry professional: "Where the revenues generated from NASDAQ market-making activities could be combined with investment banking revenues, that capital formation and provision function seemed to work. [But] with decimalization and the impact of the Elliot Spitzer Global Research Settlement, profitability has been squeezed out of the majority of that business." ${ }^{120}$ Another similar factor cited by the business community

Litan \& Anthony M. Santomero eds., 1999).

119. IPO TASK FORCE, supra note 1, at 14. For the basic facts of the settlement between major securities firms and various federal and state regulatory bodies and SROs, see Joint Press Release No. 2003-54, U.S. Sec. \& Exch. Comm'n et al., Ten of Nation's Top Investment Firms Settle Enforcement Actions Involving Conflicts of Interest Between Research and Investment Banking (Apr. 28, 2003), available at http://www.sec.gov/news/press/2003-54.htm.

120. Kenneth J. Burke, Who's Going to Pay for a New Market Structure?, TABB Forum (Sept. 13, 2010), http://www.tabbforum.com/opinions/who\%27s-going-to-pay-for-a-newmarket-structure (registration required). 
with respect to analyst coverage is Regulation Fair Disclosure, ${ }^{121}$ which effectively banned selective disclosure of certain information by issuers to securities analysts. ${ }^{122}$ This development may also have had some effect on the integrated model of market making via agency and principal transactions.

\section{INCENTIVES FOR MARKET MAKERS CONFERRING AdVANTAGES IN THE TRADING PROCESS ITSELF}

One way to incentivize market makers is to grant them various advantages in the trading process itself vis-à-vis other market participants. Such incentives can take a variety of forms, such as time, place, and information advantages or other institutional advantages, and these incentives differ in terms of transparency.

\section{A. Time, Place, and Information Advantages}

One traditional approach to incentives has been to provide market makers with time, place, and information advantages explicitly or implicitly built into the trading architecture. Such advantages are interrelated and, in addition to providing a valuable snapshot of the order flow in the relevant security, they potentially give signals with respect to fundamental information. ${ }^{123}$ On the other hand, these advantages also create conflicts of interest, as illustrated by the NYSE specialist scandal that erupted in 2003. More specifically, the specialists were accused of the following wrongdoings tied to their advantages inherent in the trading process:

121. See Selective Disclosure and Insider Trading, Securities Act Release No. 7881, Exchange Act Release No. 43,154, Investment Company Act Release No. 24,599, 65 Fed. Reg. 51,716 (Aug. 15, 2000) (to be codified at 17 C.F.R. pt. 243).

122. See, e.g., House Hearings on H.R. 3606, supra note 5, at 62 (prepared testimony of Kate Mitchell, Managing Director and Co-Founder, Scale Venture Partners, and former Chairman and current member, National Venture Capital Association); WEILD \& Kim, supra note 1, at 13; Grady, supra note 1. For a survey of empirical research on the impact of Regulation Fair Disclosure, see Stanislav Dolgopolov, Insider Trading, Informed Trading, and Market Making: Liquidity of Securities Markets in the Zero-Sum Game, 3 WM. \& MARY Bus. L. Rev. 1, 47-50 \& nn.206-16 (2012).

123. For instance, one market maker, while describing his piggybacking of orders potentially based on inside information, made the following colorful observation: "I have become like the smaller fish that swim in and out of the sharks [sic] mouth. They take the scraps that drift from the sharks [sic] meal, but stay clear of his jaws." Jon Najarian, The Options Trader, in The Super Traders: Secrets \& Successes of Wall Street's Best \& BRIGHTEST 1, 22 (Alan Rubenfeld ed., 1992). More generally, market makers may be exposed to losses by trading with better-informed counterparties under different scenarios, but there are other mitigating factors in addition to piggybacking. See generally Dolgopolov, supra note 122. 
(i) "interpositioning" in violation of the Specialist Firms' "negative obligation," in which a Specialist Firm "steps in the way" of matching orders of public sellers and / or buyers of stock to generate riskless profits to the detriment of [other market participants]; (ii) "trading ahead" or "front-running," in which Specialist Firms take advantage of their confidential knowledge of public investors' orders . . . and trade for their own account as principals before completing orders placed by public investors; (iii) "freezing the book," in which a Specialist Firm freezes its Display Book on a stock so it can first engage in trades for its own account prior to entering and then executing public investors' orders . . . . ${ }^{124}$

The rapid transformation of securities markets stripped market makers of many advantages and often blurred the line between formal and informal methods of providing liquidity. Indeed, one key development is that "changes in the business models of many exchanges and advancements in technology have eliminated or reduced the value of the special time and place privileges traditionally enjoyed by specialists and registered market makers." 125 Accordingly, some commentators have made different suggestions aimed to strengthen and formalize time, place, and information advantages available to market makers. For instance, a blue-ribbon advisory commission suggested that "measures [to encourage market making] might include preferential co-location provisions." 126 An

124. In re NYSE Specialists Sec. Litig., 260 F.R.D. 55, 64 (S.D.N.Y. 2009); see also Market Structure III: The Role of the Specialist in the Evolving Modern Marketplace: Field Hearing Before the Subcom. on Capital Mkts., Ins. \& Gov't Sponsored Enters. of the H. Comm. on Fin. Servs., 108th Cong. 56 (2004) (prepared testimony of Robert Greenfield, President and Chief Executive Officer, NASDAQ Stock Market, Inc.) (arguing that the practice of "'stepping ahead' of customer orders and a host of other occurrences with equally disturbing names like 'penny-jumping,' 'holding up cancel requests,' and 'matching the public' [were caused by NYSE specialists' exclusive access to] non-public material information about the trading characteristics of their assigned stock").

125. Letter from Greg Tusar, Managing Dir., Goldman Sachs Execution \& Clearing, L.P., \& Matthew Lavicka, Managing Dir., Goldman Sachs \& Co., to Elizabeth M. Murphy, Sec'y, U.S. Sec. \& Exch. Comm'n 7 (June 25, 2010), available at http://www.sec.gov/comments/s7-02-10/s70210-243.pdf. On the other hand, the disappearance of privileges was sometimes accompanied by the abolition of certain obligations. For instance, the NYSE's removal of the "negative obligation," i.e., the duty to abstain from certain types of proprietary trading, for designated market makers was specifically tied to the removal of informational privileges previously enjoyed by specialists. Order Approving a Proposed Rule Change by New York Stock Exchange LLC To Create a New NYSE Market Model, Exchange Act Release No. 58,845, 73 Fed. Reg. 64,379, 64,382 (Oct. 24, 2008). While the abolition of the negative obligation may potentially interfere with carrying out the affirmative obligation, numerical yardsticks addressing various dimensions of a "fair and orderly" market might keep this temptation in check.

126. JoINT CFTC-SEC AdVISORY COMM. ON EMERGING REgulATORY ISSUES, SUMMARY REPORT, RECOMMENDATIONS REgARDing REgUlAtory RESPONSES tO tHE MARKET EVENTS 
executive of a market making firm made a similar proposal: "Hold every order for a tenth of a second with the exception of market maker quote updates for products in which the market maker is registered and has affirmative obligations." ${ }^{27}$ On a similar note, there have been suggestions to tie certain existing trading features conferring time, place, and information advantages, such as the "step-up" / "flash" order functionality, to the assumption of market making obligations. ${ }^{128}$

More specifically, some of these proposals were made in the context of the capital formation crisis with the emphasis on smaller-cap stocks. For instance, one commentator suggested the following comprehensive set of trading privileges for a hypothetical trading platform for smaller-cap stocks:

$[\mathrm{M}]$ arket makers would have very specific advantages to ensure that they had greater flexibility in managing quotes and sitting on the best bid/offer [such as] co-location, minimum time in force for non-market makers, or even quote precedence over nonmarket makers. ... These structural shifts would virtually guarantee that an officially sanctioned market maker would take precedence over virtually all other traders/investors. ${ }^{129}$

The same concern was echoed by an executive of a securities exchange: "[F]or smaller cap stocks what might be more important is creating a time and place advantage for market makers rewarding them [for] providing liquidity [in such securities]." ${ }^{130}$ An academic similarly supported the idea of granting certain advantages to market makers in smaller-cap stocks in the order interaction process: "Exchanges should be able to experiment with different priority rules, such as rules that would give liquidity providers higher priority than other investors." 131

Although workable in terms of their technical requirements, these proposals still have one serious limitation. The general principle is that incentives inherent in the trading process itself are becoming more valuable

OF MAY 6, 2010, at 10 (2011), available at http://www.sec.gov/spotlight/seccftcjointcommittee/021811-report.pdf [hereinafter CFTC-SEC FLASH CRASH REPORT].

127. Thomas Peterffy, Chairman \& CEO, Interactive Brokers Grp., Comments Before the 2010 General Assembly of the World Federation of Exchanges 6 (Oct. 11, 2010), http://investors.interactivebrokers.com/download/worldFederationOfExchanges.pdf.

128. Letter from Greg Tusar \& Matthew Lavicka to Elizabeth M. Murphy, supra note 125 , at 7 .

129. Larry Tabb, A New Structure for Smaller Cap Stocks?, TABB FoRUM (Feb. 15, 2012), http://tabbforum.com/opinions/a-new-structure-for-smaller-cap-stocks (registration required).

130. House Hearing on Roadblocks in Public Markets, supra note 16, at 36 (remarks of Eric W. Noll, Executive Vice President, NTS Management, NASDAQ OMX Group, Inc.).

131. Letter from James J. Angel, Assoc. Professor of Fin., McDonough Sch. of Bus., Georgetown Univ., to U.S. Sec. \& Exch. Comm'n 9-10 (Jan. 14, 2011), available at http://www.sec.gov/comments/sr-bx-2010-059/bx2010059-5.pdf. 
with greater trading activity for the security in question. As an illustration, if a market maker has a one-second "advance look" at incoming orders, this advantage is unlikely to be very valuable for an infrequently traded - and hence illiquid - security, as opposed to a very actively traded security. Accordingly, it is much harder for a market maker to profit from these advantages while trading in infrequently traded securities, which often correspond to smaller-cap companies.

\section{B. Other Advantages}

Turning away from time, place, and information advantages of market makers, there are other ways of providing incentives inherent in the trading process. For instance, as illustrated earlier, maintaining a large tick size serves as a de facto regulatory subsidy for market makers ${ }^{132}$ - especially when combined with other advantages - and other approaches may include order flow allocation guarantees and direct payments from trading venues themselves. ${ }^{133}$

Advantages potentially available to market makers may even include an official monopoly-like franchise, and there are several formal models concluding that under certain conditions this feature might be desirable from the standpoint of economic welfare. ${ }^{134}$ For instance, one perspective

132. See Section I.B.

133. See, e.g., Eldor et al., supra note 10, at 2030 (describing various rebates and regular fixed and variable payments offered by the Tel Aviv Stock Exchange to its market makers); Najarian, supra note 123, at 21 (describing how the Chicago Board Options Exchange introduced order flow allocation guarantees in order to incentivize market makers in newly listed securities).

134. See Sandro Brusco \& Matthew O. Jackson, The Optimal Design of a Market, $88 \mathrm{~J}$. ECON. THEORY 1 (1999); Lawrence R. Glosten, Insider Trading, Liquidity, and the Role of the Monopolist Specialist, 62 J. Bus. 211 (1989); Amir Rubin, A Rationale for the Market Maker Structure, 2 J. INT'L FIN. \& ECON. 84 (2005). Fischer Black, a prominent financial economist, argued that "[c]ompetition may mean allowing multiple specialists or market makers, but encouraging a single specialist ... by giving him an official designation" in the context of the specialist system on the NYSE. N.Y. STOCK ExCH., REPORT OF THE Committee To Study the Stock Allocation System Exh. B-2, at 137 (Jan. 27, 1976). Two other prominent financial economists made an analogous observation:

Where the fixed costs are large relative to the entry-inhibiting trading risks, a competitive market may not be viable because the market makers would have no way of recovering their fixed costs of maintaining a presence on the floor [and thus] exchanges may limit the number of 'seats' available to market makers (or designate a regulated specialist).

Sanford J. Grossman \& Merton H. Miller, Liquidity and Market Structure, 43 J. FIN. 617, 629 (1988). Of course, one point of view is that "no market center should be allowed to create monopolies in the market making function." Morris Mendelson \& Junius W. Peake, Intermediaries' or Investors': Whose Market Is It Anyway?, 19 J. CoRP. L. 443, 467 (1994). 
is whether market making fits the description of a natural monopoly. ${ }^{135}$ Turning to feasible forms such an arrangement may take, there has been some advocacy for a regulatory consolidation of trading activity for certain securities - notably, securities of smaller-cap companies ${ }^{136}$ - and such measures could translate into a valuable privilege for one market maker or a group of market makers, especially in combination with other privileges. $^{137}$ Some commentators even argued that these types of

135. See Demsetz, supra note 117, at 44 ("[T] he large share of trading in which the specialist does not participate is somewhat more convincing of the absence of "natural monopoly' conditions.”); John Rust \& George Hall, Middlemen Versus Market Makers: A Theory of Competitive Exchange, 111 J. POL. ECON. 353, 391 (2003) ("[I]f there are elements of increasing returns to scale and network externalities associated with having larger populations of traders (which enable a market maker to have a 'thicker' and more 'continuous' market), there may be 'natural monopoly' elements to market making."); Seymour Smidt, Can You Get There from Here?, in MARKet Making AND the Changing STRUCTURE OF THE SECURITIES INDUSTRY 297, 298 (Yakov Amihud et al. eds., 1985) ("[T]here is substantial evidence that market making in itself is not a natural monopoly [and] that economies of scale are minimal ....").

136. See, e.g., House Hearings on H.R. 3606, supra note 25, at 45 (prepared testimony of Joseph Brantuk, Vice President, NASDAQ OMX Group) ("[T]he unintended consequences of the market fragmentation has been a lack of liquidity and price discovery in listed securities outside the top few hundred names and a disturbing absence of market attention paid to small growth companies by all market participants, including exchanges.... [T] he SEC [should be permitted] to allow emerging growth companies exemptions from today's fragmented markets during their transition period."); EVCA, WHY We Need To Fix Small Cap Markets in Europe, supra note 95, at 4 ("Fragmentation will continue to negatively impact both the IPO valuations, and aftermarket trading liquidity of small cap growth companies in Europe."). For similar proposals advanced earlier by several academics that would grant issuers control over multimarket trading - and thus essentially create a property right - by giving them the option to exclude specific trading venues or (de)authorize cross-listing, see Amihud \& Mendelson, supra note 73, passim; David D. Haddock, The Swiftness of Divine Retribution and Its Tendency to Mistake Its Target: An Analysis of the Brady Report, in The STOCK Market: BubBles, Volatility, AND ChaOs 179, 191 (Gerald P. Dwyer, Jr. \& R.W. Hafter eds., 1990). Revisiting these proposals in the context of today's fragmented securities markets, another academic similarly argued that "[such] contestable monopolies in the provision of exchange services ... can ensure that competition continues to restrain costs and promote high quality and services while at the same time providing a means to obtain benefits from consolidated market structures that presently are not possible under the currently regulatory framework." Lawrence Harris, The Homogenization of US Equity Trading 19 (Sept. 30, 2011) (unpublished manuscript) (on file with author), available at http://www.bankofcanada.ca/wpcontent/uploads/2012/11/Larry-Harris.pdf.

137. In retrospect, it is likely that the opposite process, i.e., the fragmentation of order flow brought about by technological and regulatory developments, has had an adverse effect on market makers operating on "main" trading venues and perhaps shifted emphasis towards less formal models of providing liquidity. See, e.g., CFTC-SEC Flash CRASH REPORT, supra note 126, at 10 ("The increased market competition and dramatic market fragmentation which has occurred subsequent to Regulation NMS, however, have effectively eliminated much of the profitability of the registered market maker function and therefore, eliminated the ability for the Exchanges to impose significant quoting or trading 
privileges are closely connected:

[D] uring normal times, traders will avoid markets with designated market-makers to avoid losses associated with the exercise of their special privileges. The designated market-maker thus will not be able to build their war chests. However, when called upon to meet their special responsibilities, all traders will want to trade with them. Systems with special privileges for designated market-makers can only work well in markets in which all trading is consolidated by regulation to the sponsoring market. ${ }^{138}$

On the other hand, "the outrageous suggestion that to save companies from the evils of market 'fragmentation,' public companies should be permitted to choose a sole, exchange-listed venue on which to have all broker-dealers send their trades" was attacked as "effectively creating a trading monopoly for the chosen exchange." 139

Another potential avenue to incentives for market makers is for trading venues themselves to offer certain forms of compensation. Of course, such reduced fees or monetary subsidies to market makers may come from listing fees (born by issuers), transaction fees more generally (borne by participants in the trading process), or market data revenues (born by users of these data products).

Another approach to reward providers of liquidity is the maker-taker pricing model, in which liquidity rebates are typically paid for submitting "passive" orders and funded by fees charged for submitting "aggressive" orders, ${ }^{140}$ although this model has attracted a lot of controversy. ${ }^{141}$

obligations.”). Focusing on the impact of one manifestation of fragmentation, off-exchange trading, one executive of a leading securities exchange observed that "[a substantial] level of off-exchange activity erodes the incentive for market makers to continue to trade the less active securities, has a negative effect on price discovery and threatens to further decrease the incentives for companies to go public." Computerized Trading: What Should the Rules of the Road Be? - Part II: Hearing Before the Subcomm. on Sec., Ins., \& Inv. of the S. Comm. on Banking, Hous., \& Urban Affairs, 112th Cong. 27-28 (2013) (prepared testimony of Joseph Mecane, EVP \& Head of U.S. Equities, NYSE Euronext) (footnote omitted).

138. James J. Angel et al., Equity Trading in the 21st Century: An Update, Q.J. FIN. (forthcoming) (manuscript at 33), available at http://www.knight.com/newsroom/pdfs/researchCommentary06272013.pdf. These commentators also expressed some skepticism that decisions relating to such regulatory consolidation under the SEC's or issuers' supervision "would necessarily be the best ones for the majority of public investors." Id. (manuscript at 34).

139. Letter from R. Cromwell Coulson, President \& CEO, OTC Mkts. Grp. Inc. to Tim Johnson, Chairman, and Richard Shelby, Ranking Member, Comm. on Hous., Banking, \& Urban Affairs, U.S. Senate 8 (Dec. 8, 2011), reproduced in Senate Hearing on Spurring Job Growth Through Capital Formation I, supra note 18, at 100.

140. For a detailed discussion of the maker-taker model, see Thierry Foucault, Pricing Liquidity in Electronic Markets (U.K. Gov't Office for Sci., The Future of Computer Trading in Financial Markets - Foresight, Driver Review No. 18, 2012), available at 
Furthermore, the maker-taker pricing model reinforces informal market making as a "structure that rewards any participant that provides liquidity and charges those who consume liquidity," 142 although this model is not necessarily incompatible with the existence of designated market makers, which may even receive greater liquidity rebates compared to everyone else. ${ }^{143}$ As a counter-argument, one commentator maintained that the maker-taker pricing model "doesn't incentivize true liquidity providers, it incentivizes rebate arbitrage and market structure arbitrage, and that's a problem," while noting that "a part of re-examining our market structure should be re-examining how to incentivize true liquidity providers, at the very least in small and mid-cap names."144 The same commentator also suggested that the eligibility to receive rebates from trading venues under the maker-taker pricing model should be tied to the assumption of market making obligations. ${ }^{145}$ Interestingly, an empirical study of options markets

http://www.bis.gov.uk/assets/foresight/docs/computer-trading/12-1051-dr18-pricing-

liquidity-in-electronic-markets.pdf.

141. See, e.g., James J. Angel et al., Equity Trading in the 21st Century, 1 Q.J. FIN. 1, 39 (2011) ("[The maker-taker pricing model] has distorted order routing decisions, aggravated agency problems among brokers and their clients, unleveled the playing field among dealers and exchange trading systems, produced fraudulent trades, and produced quoted spreads that do not represent actual trading costs."); Letter from Anthony J. Saliba, Chief Exec. Officer, LiquidPoint, LLC to Elizabeth Murphy, Sec'y, U.S. Sec. \& Exch. Comm'n 4 (July 9, 2010), available at http://www.sec.gov/comments/s7-09-10/s70910-32.pdf ("Even with fee limitations, the make or take fee structure promotes the ephemeral liquidity of orders in a market that depends upon quotes [such as an options market], at the expense of the [traditional] model - ultimately to the detriment of the investor.").

142. Letter from John A. McCarthy, Gen. Counsel, Global Elec. Trading Co., to Elizabeth M. Murphy, Sec'y, U.S. Sec. \& Exch. Comm'n 5 (June 23, 2010), available at http://www.sec.gov/comments/s7-09-10/s70910-25.pdf; see also Anthony Saliba et al., Ephemeral Liquidity in a Purely Order-Driven Market, TABв ForUm (May 23, 2010), http://tabbforum.com/opinions/ephemeral-liquidity-in-a-purely-order-driven-market

(registration required) ("[T]he liquidity in the equities market, and now in the options market, is increasingly being provided by firms whose sole incentive for providing liquidity is the 'maker' rebates they are paid by exchanges. Unlike the traditional market-maker and specialist systems, these entities have no obligation to provide liquidity, just the incentive provided by the rebate they receive every time a market participant takes liquidity from them.").

143. See Amber Anand et al., Incentives for Liquidity Provision: Is the Make-Take Structure the Answer? App. A.2 at 31 (May 2013) (unpublished manuscript) (on file with author), available at http://ssrn.com/abstract=2074318 (observing that "[m]ake rebates and take fees [are] typically higher for [designated] market makers" and that, on some trading venues, only these market participants are eligible to receive liquidity rebates).

144. Interview by Mike O'Hara with Dave Lauer, Fixing the US Equity Market Structure, HFT REV. (July 12, 2013), http://www.hftreview.com/pg/blog/mike/read/106012 (registration required).

145. Id.; see also Senate Hearings on Computerized Trading - Part I, supra note 110, at 37 (prepared testimony of David Lauer, Market Structure and High-Frequency Trading Consultant, Better Markets). 
comparing the maker-taker and traditional pricing models came to the following conclusion:

The make-take structure provides better execution quality and is primarily responsible for improving quoted prices, but only covers a small, high-volume subset of listed options. The traditional structure provides greater coverage of less liquid securities and is more likely to improve on the quoted depth at the best quotes. The increased coverage by the traditional structure likely imposes greater market making costs, which are recovered through higher transaction costs for liquidity demanders. ${ }^{146}$

This result somewhat resonates with earlier attacks on the maker-taker pricing model in options markets, ${ }^{147}$ and it also indirectly raises the issue of optimizing incentives for providing liquidity in smaller-cap stocks.

Yet, overall, as with time, place, and privilege advantages, there is a danger that other advantages inherent in the trading process itself might not be sufficiently valuable to attract capital commitment, as such advantages ultimately depend on the "natural" level of liquidity provided by participants in the trading process. On the other hand, some institutional arrangements may indirectly involve other parties, such as issuers.

\section{ISSUER-TO-MARKET MAKER COMPENSATION ARRANGEMENTS}

One approach to providing incentives for market makers is allowing them to receive payments from issuers or affiliates of issuers. In fact, concrete issuer-to-market maker compensation arrangements are on the agenda after having been scrutinized for their desirability as such, as well as their specific features.

\section{A. The Continuing Controversy}

One potential incentive is an issuer-to-market maker compensation arrangement with fixed or variable payments that would flow to market makers directly or through trading venues in exchange for maintaining certain liquidity benchmarks. Such compensation arrangements, however,

146. Anand et al., supra note 143, at i.

147. See, e.g., Letter from John C. Nigel, Managing Dir. \& Gen. Counsel, Asset Mgmt. \& Mkts., Citadel LLC, to Elizabeth Murphy, Sec'y, U.S. Sec. \& Exch. Comm'n (Aug. 6, 2010), available at http://www.sec.gov/comments/s7-21-09/s72109-144.pdf ("[Traditional] exchanges provide deep liquidity for a diverse range of options, reward quoting in size and have market makers with affirmative quoting obligations across the full range of options in assigned symbols. In contrast, high access fee exchanges primarily quote only the most liquid contracts and their liquidity providers are mostly 'fair weather' proprietary traders without any quoting obligations and who trade to collect rebates."). 
have been effectively prohibited in the United States until very recently.

Opponents have argued against such compensation arrangements for decades. In 1973, for example, regulators expressed their concern that, "[i]n view of the common understanding of a market maker's role and economic motivations, an arrangement whereby a broker-dealer charges an issuer a fee for making a market in its stock may conflict with the antifraud provisions of the federal securities laws." ${ }^{\text {"148 }}$ Similarly, the NASD expressed the view that " $[\mathrm{t}]$ he additional factor of payments by an issuer to a market maker would probably be viewed as a conflict of interest since it would undoubtedly influence, to some degree, a firm's decision to make a market and thereafter, perhaps, the prices it would quote." 149 In 1997, the SEC approved a rule proposed by the NASD, as a codification of this SRO's long-standing policy, that prohibited issuer-to-market maker compensation arrangements, and the regulatory agency stated that "the rule preserves the integrity of the marketplace by ensuring that quotations accurately reflect a broker-dealer's interest in buying or selling a security." "150 The Financial Industry Regulatory Authority ("FINRA"), the NASD's successor, also stood by this rule. ${ }^{151}$

Various forms of issuer-to-market maker compensation arrangements proliferated, however, before and probably after the prohibition, . One commentator described the problem of stimulating liquidity in the over-thecounter market for an emerging company as follows:

A trading market assumes one or more dealers prepared to make a market and such dealers often expect to be paid a price for making a market. What that price is may depend upon what the dealer is able to extort and the dealer's own concept of respectability. In any event, it may involve access to the company's shareholder's list; daily advice as to transfers; preferential access to information; membership on the company's board; the company's cooperation in distributing information about the company; a block of cheap stock or access to an available supply of stock or what have you. In fact, most marketmakers regard what they are doing as being of some value to the

148. Monroe Sec., Inc., SEC No-Action Letter, 1973 SEC No-Act. LEXIS 2653, at*1-2 (June 4, 1973).

149. Nat'l Ass'n of Sec. Dealers, Inc., Payments by Issuers to Market Makers, NTM No. 75-16, 1975 NASD LEXIS 32, at*2 (Feb. 20, 1975).

150. Order Approving a Proposed Rule Change by National Association of Securities Dealers, Inc. Relating to Prohibition on Members Receiving Any Payment To Publish a Quotation, Make a Market in an Issuer's Securities or Submit an Application to Make a Market in an Issuer's Securities, Exchange Act Release No. 38,812, 62 Fed. Reg. 37,105, 37,106-07 (July 3, 1997).

151. Order Approving Proposed Rule Changes by Financial Industry Regulatory Authority, Inc., Exchange Act Release No. 60,534, 74 Fed. Reg. 44,410, 44,411 (Aug. 19, 2009). 
company and may demand one price or another (often willingly paid) - some legal and others illegal or questionable in this legal nether land-in return for making a market in this context. ${ }^{152}$

Furthermore, there are some indications that similar arrangements had been in place in more established markets, such as securities exchanges. For instance, as suggested several decades ago, an exchange specialist was "often provided with 'inside' information by the management of 'his' corporation before an official announcement is made. Yet his dealings are not open to the same public scrutiny as are those of more formal 'insiders." "153

Several trading venues have lobbied for the adoption of issuer-tomarket maker compensation arrangements for certain types of securities, including smaller-cap stocks. ${ }^{154}$ The SEC recently approved two programs on a pilot basis after a lengthy review. The program introduced by NASDAQ allows issuers of certain securities - which could be broadly defined as exchange-traded products, such as exchange-traded funds, equity index-linked products, and basket-based products - to compensate

152. Harold S. Bloomenthal, Market-Makers, Manipulators and Shell Games, 45 ST. JoHN's L. REV. 597, 603 (1971) (footnote omitted). The same commentator favored "a rule making it unlawful for a broker-dealer to request and/or accept any consideration direct or indirect for making a market or placing quotations in the sheets (or other quotation system) for a security" and proposed creating "a subsidized, computerized marketplace [for emerging companies] administered by a public corporation in which transactions take place only on an agency auction basis." Id. at 641-42. The latter recommendation was based on the assumption "that the reason market-makers exist in the over-the-counter market is the fact that there is no central clearing market at which orders can be matched." id. at 641-42 n. 178 , but this assumption is questionable.

153. Ralph James \& Estelle James, Disputed Role of the Stock Exchange Specialist, HARV. Bus. REV., May-June 1962, at 133, 138. A contemporary study conducted by the SEC also addressed this concern, noting the existence of somewhat conflicting NYSE policies that prohibited its specialists from acquiring inside information and yet encouraged them to maintain liaison with issuers, as well as possible instances of leakages of inside information from issuers to specialists. RePORT of Special Study of Securities Markets of the Securities and Exchange Commission, H.R. Doc. No. 88-95, pt. 2, ch. VI, at 15760 (1963). Ultimately, the study did not uncover any quid pro quo arrangements - whether specifically tied to the maintenance of liquidity or otherwise- but it observed that issuers and specialists "may have confidential information of value to the other - on the one side corporate information and on the other technical information concerning the book and possible short-range price movements." Id. at 159. Other commentators expressed a concern that "contacts [between specialists and company officials] may lead to improper leaks of inside news and influence over the actions of the specialist." NiCHOLAS WOLFSON et al., Regulation of Brokers, Dealers and Securities Markets 9 11.07, at 11-41 (1977).

154. See Nina Mehta, Payments to Market Makers May Improve Trading in Smaller Stocks, NYSE Says, BLOOMBERG, Nov. 15, 2011, available at http://www.bloomberg.com/news/2011-11-15/payments-to-market-makers-may-improvetrading-in-smaller-stocks-nyse-says.html. 
market makers. ${ }^{155}$ In this type of arrangement, the trading venue would serve as a conduit. The program introduced by NYSE Arca similarly allows issuers of exchange-traded products to compensate market makers through the trading venue. ${ }^{156}$ The applicable FINRA rule was also revised accordingly. ${ }^{157}$

The implementation and subsequent functioning of these programs could inform decisions about the feasibility of such arrangements for smaller-cap stocks, as opposed to exchange-traded products, ${ }^{158}$ although some commentators have pointed out that market making in the latter securities has its own unique risks. ${ }^{159}$ In fact, NASDAQ stated that "while

155. Approving a Proposed Rule Change by NASDAQ Stock Market LLC To Establish the Market Quality Program, Exchange Act Release No. 69,195, 78 Fed Reg. 18,393 (Mar. 20, 2013) [hereinafter Approval Order for NASDAQ]; see also Notice of Filing of a Proposed Rule Change by NASDAQ Stock Market LLC To Establish the Market Quality Program, Exchange Act Release No. 66,765, 77 Fed. Reg. 22,042 (Apr. 6, 2012) [hereinafter NASDAQ's Original Proposal] (describing the original proposal); Notice of Withdrawal of Proposed Rule Change by NASDAQ Stock Market LLC To Establish the Market Quality Program, Exchange Act Release No. 68,378, 77 Fed. Reg. 74,042 (Dec. 6, 2012) (notifying about the withdrawal of the original proposal and describing the content of its amendments); Notice of Filing of a Proposed Rule Change by NASDAQ Stock Exchange LLC To Establish the Market Quality Program, Exchange Act Release No. 68,515, 77 Fed. Reg. 77,141, 77,147 (Dec. 21, 2012) [hereinafter NASDAQ's Revised Proposal] (describing the revised proposal).

156. Order Approving a Proposed Rule Change by NYSE Arca, Inc. To Implement a One-Year Pilot Program for Issuers of Certain Exchange-Traded Products, Exchange Act Release No. 69,706, 78 Fed. Reg. 35,340 (June 6, 2013) [hereinafter Approval Order for NYSE Arca]; see also Notice of Filing of a Proposed Rule Change by NYSE Arca, Inc. for a Pilot Program To Create a Lead Market Maker Issuer Incentive Program for Issuers of Certain Exchange-Traded Products, Exchange Act Release No. 66,966, 77 Fed. Reg. 29,419 (May 11, 2012) [hereinafter NYSE Arca's Original Proposal] (describing the original proposal); Notice of Withdrawal of Proposed Rule Change by NYSE Arca Inc. for a Pilot Program To Create a Lead Market Maker Issuer Incentive Program for Issuers of Certain Exchange-Traded Products, Exchange Act Release No. 68,616, 78 Fed. Reg. 3482 (Jan. 10, 2013) (notifying about the withdrawal of the original proposal); Notice of Filing of a Proposed Rule Change by NYSE Arca, Inc. To Implement a One-Year Pilot Program for Issuers of certain Exchange-Traded Products, Exchange Act Release No. 69,335, 78 Fed. Reg. 21,681 (Apr. 5, 2013) (describing the revised proposal).

157. Order Approving a Proposed Rule Change by Financial Industry Regulatory Authority, Inc. Relating to FINRA Rule 5250 (Payments for Market Making), Exchange Act Release No. 69,398, 78 Fed. Reg. 24,261 (Apr. 18, 2013).

158. One trading venue even suggested that its program even in its current form may aid the capital formation process for "less well known or start-up companies": "Being included in a successful [exchange-traded fund] can provide the stocks of these companies with enhanced liquidity and exposure, enabling them to attract investors and access capital markets to fund investment and growth." NASDAQ's Original Proposal, supra note 155, at $22,043 \&$ n.12. On the other hand, some commentators have questioned the overall benefit for a smaller company of having its securities included in an exchange-traded fund. See Bradley \& Litan, supra note 1, at 39-40.

159. See Letter from Andrew Stevens, Legal Counsel, IMC Chi., LLC d/b/a IMC Fin. Mkts., to Elizabeth M. Murphy, Sec'y, U.S. Sec. \& Exch. Comm'n 3 (Aug. 16, 2012), 
the [program] pilot is structured to initially apply only to [exchange-traded funds], the goal is to expand the successful [program] to small cap stocks and other similar products that may need liquidity enhancement. ${ }^{160}$ This compensation arrangement is specifically envisioned for the BX Venture Market, NASDAQ's proposed trading platform for smaller-cap / emerging companies. ${ }^{161}$ The SEC, however, is hardly "enthusiastic about expanding coverage to operating companies." $"$ On the other hand, a bill recently introduced in the U.S. Congress stresses the need to "promote enhanced trading and price-discovery for smaller public companies" $" 163$ and provides a safe harbor for securities exchanges' programs "under which the exchange, an entity that lists securities . . . an entity determined appropriate by the [SEC], or any other entity determined appropriate by [the] exchange, provides financial incentives to market makers that adhere to standards of market quality established by the rules of the exchange." 164

\section{B. The Rationale Behind the Underlying Mechanism}

Given potential conflicts of interest, it is critical to articulate the rationale behind issuer-to-market maker compensation arrangements. Their use strikes at the heart of the problem of liquidity externalities, as illustrated by a formal model of price stabilization-which could be thought of as a dimension of liquidity - by designated market makers: "[S]tabilization is a public good type external economy to investors [and] current restrictions on corporation-stabilizer contracts preclude a free market in supplementary stabilization and result in nonoptimal amounts being supplied." 165 While an issuer may or may not be a direct participant

available at http://www.sec.gov/comments/sr-nysearca-2012-37/nysearca201237-10.pdf.

160. NASDAQ's Revised Proposal, supra note 155, at 77,145.

161. See Mehta, supra note 154.

162. Peter Chapman, 'Paid-For-Market-Making' Deadline Looms, Traders MAG. Online News (Nov. 21, 2012), http://www.tradersmagazine.com/news/pfof-market-makingpayment-110556-1.html (registration required).

163. Liquidity Enhancement for Small Public Companies Act, H.R. 6127, 112th Cong. pmbl. (2012).

164. Id. $\S 2$ (a). The bill appears to correspond to the proposals by NASDAQ and NYSE Arca. See Peter Chapman, Bill Proposed To Support Small Caps, Traders Mag., Aug. 2012, at 16, 16 (explaining the bill and its rationale). Given that these programs envision a flow of payments from issuers to market makers through the trading venues themselves, the bill would similarly require that such payments are to be "paid only by [the] exchange and may not be paid directly to a market maker by an entity that lists securities on the exchange." H.R. 6127 § 2(a).

165. Cohen et al., supra note 9, at 245; see also id. at 239 (treating price stabilization as a public good and immediacy as a private good); Harris, supra note 136, at 17 (analyzing transactions in stocks on the NYSE and the American Stock Exchange and providing empirical evidence to "suggest that specialist stabilization substantially reduced transitory volatility in the listed stocks until growing competition from other liquidity supplying 
in transactions in its own securities, ${ }^{166}$ going beyond participants in the trading process in order to incentivize market making may expand the size of the pie. ${ }^{167}$ Essentially, an issuer may split the economic benefits of greater liquidity of its securities - and hence potentially higher valuationwith a market maker. ${ }^{168}$ More generally, in the absence of side payments from issuers, market making as such may be unprofitable. ${ }^{169}$ Even in the context of the maker-taker model, which explicitly compensates market participants for providing liquidity, payments from an issuer to a market maker may increase economic efficiency:

One of the circular issues is that there's, in some of these

traders make it impossible to continue providing these services."). Interestingly, a much later formal model also tackled the same problem - with the assumption that the only cost borne by market makers stems from inherent informational asymmetries - and concluded that issuer-to-market maker compensation arrangements "can potentially improve [firm] value and welfare because of an information-based externality." Hendrik Bessembinder et al., Market Making Obligations and Firm Value 4, 31 (Sept. 2013) (unpublished manuscript) (on file with author), available at http://www.nes.ru/dataupload/files/events/Researchseminar/DMM.September2013sm.pdf.

While this information-based cost is relevant for illiquid securities, for which market makers would find it more problematic to engage in inventory management, it is less likely to be the dominant one. Furthermore, one academic study predicted that issuer-to-market maker compensation arrangements are unlikely to improve market quality because "inactive stocks are already subject to greater informed trading and that the firm may not have the optimal incentives from the perspective of uninformed traders." David Easley et al., Information, and Infrequently Traded Stocks, 51 J. FIN. 1405, 1429 n.33 (1996). However, this prediction appears not to have materialized.

166. Several empirical studies in fact suggest that issuers are more likely to contract with market makers around such events as secondary offerings and repurchases, i.e., when issuers themselves participate in the trading process. See Amber Anand et al., Paying for Market Quality, 44 J. Fin. \& QUANT. ANALYsis 1427, 1429 (2009) (evidence from transactions in stocks on the Stockholm Stock Exchange); Skjeltorp \& Ødegaard, supra note 9, at 3 (evidence from transactions in stocks on the Oslo Stock Exchange).

167. As an illustration, an extrapolated sample employed by an empirical study of transactions in stocks on the Stockholm Stock Exchange indicates that every dollar of the aggregate maximum possible payment to market makers from issuers generates approximately 5.4 dollars in savings to market participants in the form of lower transaction costs. See Anand et al., supra note 166, at 1432 tbl.1, 1445.

168. See also Venkataraman \& Waisburd, supra note 8, at 740 ("[T] will need additional compensation outside of trading revenues for maintaining a market presence.... Because the listing firm enjoys a positive externality of market maker presence (in the form of a lower cost of capital), one obvious source for subsidizing market maker revenues is the listing firm itself.").

169. For instance, one empirical study examined Xetra's designated market makers, entities with affirmative obligations that are compensated by issuers and found that these market participants "do, on average, not earn profits on their trading activities" despite their fee- and information-based advantages in the trading process. Erik Theissen et al., Designated Market Makers in Electronic Limit Order Books - A Closer Look 4, 6-7 (Jan. 15,2013 ) (unpublished manuscript) (on file with author), available at http://events.emlyon.com/AFFI/Papers/295.pdf. 
[smaller-cap] names, not-we're paying out all the revenue that we generate and it's not necessarily enough to help get the liquidity to where we would like it to be. That's part of the reason for why we think the experiment of also letting issuers compensate market makers could help, because in some circumstances, we're already paying all the revenue we have because most of that is on a per-transaction basis and these issues don't trade very frequently. It doesn't generate enough revenue to necessarily incentivize the liquidity providers. ${ }^{170}$

In addition, these compensation arrangements as direct subsidies to market makers compare favorably to indirect subsidies, such as time, place, and information advantages, given that the latter type tends to be less valuable in illiquid markets and generally less transparent. Similarly, the hypothetical in which other market participants cherry-pick transactions with market makers could be avoided. ${ }^{171}$

The use of economic analysis has found its place in the current debates. For instance, NASDAQ's proposal heavily relied on the existing empirical studies produced by academics and its own experience with issuer-to-market maker compensation arrangements on the First North Market, one of its European subsidiaries. ${ }^{172}$ On the other hand, even the advocates of such compensation arrangements pointed to potential difficulties presented by the contrast between centralized foreign securities markets and fragmented securities markets common in the United States. ${ }^{173}$

170. House Hearing on Roadblocks in Public Markets, supra note 16, at 35 (remarks of Joseph Mecane, Executive Vice President and Chief Administrative Officer, U.S. Markets, NYSE Euronext).

171. For a description of this hypothetical, see supra note 138 and accompanying text.

172. NASDAQ's Original Proposal, supra note 155, at 22,044-45. In fact, the proposal itself was viewed favorably by the academic community. See Letter from Joan C. Conley, Senior Vice President \& Corporate Sec'y, NASDAQ OMX LLC, to Elizabeth M. Murphy, Sec'y, U.S. Sec. \& Exch. Comm'n 6-10 (July 6, 2012), available at http://www.sec.gov/comments/sr-nasdaq-2012-043/nasdaq2012043-21.pdf. For a sample of relevant academic studies, see Anand et al., supra note 166, at 1427 (analyzing transactions in stocks on the Stockholm Stock Exchange and concluding that the introduction of designated market makers compensated by issuers leads to "a decreased cost of capital and significant improvements in market quality and price discovery"); Albert J. Menkveld \& Ting Wang, How Do Designated Market Makers Create Value for Small-Caps?, 16 J. FIN. MKTS. 571, 571 (2013) (analyzing transactions in stocks on Euronext Paris and concluding that the introduction of designated market makers compensated by issuers "improves liquidity level, reduces liquidity risk, and generates an average abnormal return of 3.5\%"); Venkataraman \& Waisburd, supra note 8, at 735 (analyzing transactions in stocks on the Paris Bourse and concluding that after the introduction of designated market makers compensated by issuers "stocks experience an average cumulative abnormal return of nearly $5 \%$ that is positively correlated with improvements in liquidity").

173. See House Hearing on Roadblocks in Public Markets, supra note 16, at 38 (remarks of Joseph Mecane, Executive Vice President and Chief Administrative Officer, U.S. Markets, NYSE Euronext); Letter from Amber Anand, Assoc. Professor of Fin., 
To illustrate one of these concerns, one academic argued that "fragmented market raises the possibility that order flow will be diverted to [designated market makers] only when liquidity is scarce, which would exacerbate the adverse selection problem faced by [them]." ${ }^{, 174}$

One key issue pertaining to issuer-to-market maker compensation arrangements is whether they may crowd out non-sponsored securities with similar characteristics and thus create economic inefficiencies. NASDAQ responded to the charge that its proposal may end up creating a pay-to-play environment by arguing that the benefits of participation would still outweigh its costs and that the proposal "was designed as a competitive program for a competitive marketplace."175 More broadly, the pay-to-play scenario is a legitimate concern, but it is overly pessimistic. Much depends on whether market participants would treat the existence of a paid market maker as the chief signal of current and future liquidity.

Commentators have attacked, however, the very goal of higher liquidity associated with issuer-to-market maker compensation arrangements. One argument is as follows:"Narrow spreads primarily benefit investors engaged in frequent trading strategies, whereas higher expenses primarily hurt long-term, buy-and-hold investors. ... [I]t is not in the public interest for long-term shareholders (typically retail investors) to subsidize frequent traders (typically large institutions)." ${ }^{, 176}$ The counterargument is that increased liquidity and hence valuation could benefit both short-term and long-term investors. ${ }^{177}$ Furthermore, in the context of many securities, such as smaller-cap stocks, increased liquidity would not necessarily generate a lot of high-frequency-style trading. On a related note, it is hard to agree with the view that the proposed incentive mechanism "carries little risk for intermediaries, who profit simply through participating." 178 Market makers would still be exposed to the forces of price fluctuations.

Of course, various conflicts of interest are inherent in issuer-to-market

Whitman Sch. of Mgmt., Syracuse Univ., to Elizabeth M. Murphy, Sec'y, U.S. Sec. \& Exch. Comm'n 3 (Apr. 29, 2012), available at http://sec.gov/comments/sr-nasdaq-2012043/nasdaq2012043-9.pdf.

174. Letter from Amber Anand to Elizabeth M. Murphy, supra note 173, at 3.

175. Letter from Joan C. Conley to Elizabeth M. Murphy, supra note 172, at 18.

176. Letter from F. William McNabb, Chairman \& Chief Exec. Officer, Vanguard, to Elizabeth M. Murphy, Sec'y, U.S. Sec. \& Exch. Comm'n 3 (Aug. 16, 2012), available at http://www.sec.gov/comments/sr-nysearca-2012-37/nysearca201237-8.pdf.

177. Letter from Joan C. Conley, Senior Vice President \& Corporate Sec'y, NASDAQ OMX LLC, to Elizabeth M. Murphy, Sec'y, U.S. Sec. \& Exch. Comm'n 13 (Aug. 30, 2012), available at http://www.sec.gov/comments/sr-nasdaq-2012-043/nasdaq201204327.pdf.

178. Letter from Timothy Quast, Managing Dir., ModernIR LLC, to Elizabeth M. Murphy, Sec'y, U.S. Sec. \& Exch. Comm'n 2 (Apr. 26, 2012), available at http://sec.gov/comments/sr-nasdaq-2012-043/nasdaq2012043-11.pdf. 
maker compensation arrangements. For instance, as stated by a representative of the securities industry,

Issuers who pay market makers, directly or indirectly, may be even more emboldened to push those market makers to artificially prop up their share prices in the face of any number of legitimate market forces-such as unflattering news or short selling - or, simply, if management believes the market is not recognizing the company's true value. ${ }^{179}$

One securities industry group also expressed apprehension about such compensation arrangements: "We would have reservations were the [proposed compensation arrangements] to apply to single-name securities, as we believe that payment by corporate issuers for market-making could change the market dynamics." 180 Even NYSE Arca itself used the argument for the adoption of its proposal that exchange-traded products, as derivative securities, do not present the same concerns as securities of individual companies. ${ }^{181}$ NASDAQ also made a similar argument that "the products that we believe is [sic] most likely to participate in the [proposed program], [exchange-traded funds], have a structure that inherently protects against, and effectively eliminates, the opportunity for price manipulation by a market maker." 182

On the other hand, the choice is among imperfect alternatives, and the lack of other approaches to incentivizing market makers favors the adoption of issuer-to-market maker compensation arrangements even for equity securities. Not surprisingly, a representative of a technology industry group noted that a program similar to NASDAQ's "could benefit promising tech companies that today may lack liquid, quality markets." 183 Furthermore, the experience of foreign equity markets is informative. For instance, an academic stated that he was "not aware of a single instance of purported collusion between issuers and market makers in the ten years since the direct payments have existed outside the US," ultimately

179. House Hearing on Market Structure, supra note 16, at 89 (prepared testimony of Joseph C. Gawronski, President and Chief Operating Officer, Rosenblatt Securities).

180. Letter from Stuart J. Kaswell, Exec. Vice President, Managing Dir. \& Gen. Counsel, Managed Funds Ass'n, to Elizabeth M. Murphy, Sec'y, U.S. Sec. \& Exch. Comm'n 2 (July 3, 2012), available at http://sec.gov/comments/sr-nasdaq-2012043/nasdaq2012043-19.pdf.

181. See NYSE Arca's Original Proposal, supra note 156, at 29,422 (arguing that "issues associated with securities of operating companies... are not present with [exchange-traded products], which have derivative pricing, creation and/or redemption features, or upsizing that would preclude the type of manipulation").

182. Letter from Joan C. Conley to Elizabeth M. Murphy, supra note 172, at 15.

183. Letter from Rey Ramsey, President \& CEO, TechNet, to Elizabeth M. Murphy, Sec'y, U.S. Sec. \& Exch. Comm'n 1 (June 20, 2012), available at http://www.sec.gov/comments/sr-nasdaq-2012-043/nasdaq2012043-17.pdf. 
concluding that "[m]anipulation will not be an issue."184 Of course, the involvement of market makers in manipulative schemes in cooperation with issuers and their insiders is not unknown in the United States, especially in the context of illiquid securities, ${ }^{185}$ but perhaps the administration of such incentive programs by trading venues would be a mitigating factor.

\section{Structuring Issues}

There are several approaches to structuring issuer-to-market maker compensation arrangements. One consideration, relevant to the existing programs, is whether compensating multiple market makers or just one market maker is more appropriate. ${ }^{186}$ Indeed, one of the earliest analyses of this issue suggested that "paying multiple supplementary stabilizers for a security would be inefficient because of the 'free rider' possibilities inherent in the production of stabilization." 187 A recent comment on the proposed market maker incentive programs similarly maintained that "[a]ssigning only one eligible market maker for receipt of the incentive payment . . . maximizes the available incentive and assures accountability [while] diffus[ing] the incentive across multiple market makers may ultimately reduce the effectiveness of the incentive as well as lessen the accountability of any one market maker." ${ }^{188}$ On the other hand, this

184. Letter from Daniel G. Weaver, Professor of Fin. \& Assoc. Dir., Whitcomb Ctr. for Research in Fin. Servs., Rutgers, State Univ. of N.J., to Elizabeth M. Murphy, Sec'y, U.S. Sec. \& Exch. Comm'n 6 (Apr. 26, 2012), available at http://sec.gov/comments/sr-nasdaq2012-043/nasdaq2012043-10.pdf.

185. See, e.g., United States v. Rosen, 409 F.3d 535, 538 (2d Cir. 2005); United States v. Manas, 272 F.3d 159, 162 (2d Cir. 2001); United States v. Graulich, No. 93-1061, 1994 U.S. App. LEXIS 25466, at *2-4 (10th Cir. Sept. 13, 1994).

186. This distinction is crucial for the existing programs, as NASDAQ preferred multiple compensated market makers, while NYSE Arca selected the single market maker approach. See Approval Order for NASDAQ, supra note 155, at 18,394; Approval Order for NYSE Arca, supra note 156, at 35,341; see also Order Instituting Proceedings To Determine Whether To Approve or Disapprove Proposed Rule Changes by NASDAQ Stock Market LLC and NYSE Arca, Inc. Relating to Market Making Incentive Programs for Certain Exchange-Traded Products, Exchange Act Release No. 67,411, 77 Fed. Reg. 42,052, 42,070 (July 11, 2012) [hereinafter SEC's Order Instituting Proceedings Relating to Market Maker Incentive Programs]. However, NYSE Arca left some room for competing market makers in the future. Letter from Janet McGinness, EVP \& Corporate Sec'y, Gen. Counsel, NYSE Markets, NYSE Euronext, to Elizabeth M. Murphy, Sec'y, U.S. Sec. \& Exch. Comm'n 6-7 (Aug. 14, 2012), available at http://sec.gov/comments/sr-nysearca2012-37/nysearca201237-6.pdf. On the other hand, NASDAQ reserved the right to limit"on a program-wide basis"- the number of compensated market makers per security. Approval Order for NASDAQ, supra note 155, at 18,394.

187. Cohen et al., supra note 9, at 243.

188. Letter from Andrew Stevens to Elizabeth M. Murphy, supra note 159, at 7. 
concern appears to be at least partially mitigated by the specificity of the applicable obligations of market makers, such as those in the program introduced by NASDAQ. ${ }^{189}$ The same factor would mitigate potential anticompetitive effects of having just one compensated market maker, and the program introduced by NYSE Arca is also quite detailed in that respect. ${ }^{190}$ In any instance, the coexistence of these two pilot programs for similar securities would offer a valuable opportunity to compare such alternative arrangements and allow making inferences about an optimal form.

Another key issue is the extent of oversight exercised by a trading venue over the payment program in question. As suggested decades ago, "To avoid the possibility of stock manipulation, the listing corporation should contract for stabilization with the exchange rather than directly with [designated market makers as] stabilizers. The exchange should be responsible for choosing stabilizers and regulating them."191 NASDAQ and NYSE Arca employed the same rationale in connection with their proposals, maintaining that potential conflicts of interest would be mitigated by the transparent administration of issuer-to-market maker compensation arrangements by the trading venues in question compared to direct dealings between issuers and market makers. ${ }^{192}$ In fact, NASDAQ argued that "[an issuer] can never choose [a market maker], nor influence how, when, or the specific amount that [a market maker] receives as credit for making a market [because] these functions are performed solely by the [trading venue] according to [pre-established] standards." ${ }^{193}$ In the presence of an intermediary, however, transparency may decrease when there are several business relationships between an issuer and a market making firm. ${ }^{194}$ Yet, more generally, the involvement of trading venues in administering and monitoring such compensation arrangements is likely to be a bonding mechanism that puts into play their reputational capital and an additional level of scrutiny. Although they are not completely unbiased parties, trading venues still have an incentive to go after and prevent abuse. ${ }^{195}$

189. See Approval Order for NASDAQ, supra note 155, at 18,395-96.

190. See Approval Order for NYSE Arca, supra note 156, at 35,342-43.

191. Cohen et al., supra note 9, at 243.

192. See Letter from Joan C. Conley to Elizabeth M. Murphy, supra note 172, at 15; Letter from Janet McGinness, to Elizabeth M. Murphy, supra note 186, at 3.

193. NASDAQ's Revised Proposal, supra note 155, at 77,147.

194. See, e.g., Venkataraman \& Waisburd, supra note 8, at 742 (hypothesizing that investment banking revenues - rather than explicit payments - are likely to be a more important form of compensation for market making activities for securities firms operating on the Paris Bourse).

195. Arguably, manipulative schemes involving market makers and issuers or their insiders have been more prominent in over-the-counter markets than organized securities 
Yet another issue concerns potential time limits for specific securities for participating in issuer-to-market maker compensation arrangements. ${ }^{196}$ While one might focus on externalities during the initial stage of a security's lifecycle, ${ }^{197}$ it is entirely possible that a continued subsidization of market making activities may be required at later stages - depending on the liquidity characteristics of the security in question - in order to increase economic efficiency. Accordingly, a time limit on participation in a market maker incentive program might not be necessary as a hard constraint. In fact, the programs introduced by NASDAQ and NYSE Arca specifically tie their respective termination mechanisms to the achievement of a specific trading volume-based benchmark, ${ }^{198}$ which is a sensible approach.

\section{INTEGRATED MODEL OF MARKET MAKING}

One pivotal issue pertains to the integrated model of market making from the standpoint of incentives provided on different stages and crosssubsidization between market making and related activities. Another corresponding question is whether the integrated model has any inherent advantages - especially in the context of smaller-cap stocks.

\section{A. Bundling and the Economies of Scope}

A pivotal issue is to what extent market making is "complementary" to other functions because of the economies of scope enjoyed by a typical multifunctional securities firm or even an essential component of a bundle of services that such a firm provides. While the move to the integrated model is a manifestation of general consolidation in the financial marketplace, ${ }^{199}$ this model probably has an economic rationale as well.

exchanges, which would also favor the proposed type of intermediation.

196. See SEC's Order Instituting Proceedings Relating to Market Maker Incentive Programs, supra note 186, at 42,069.

197. See Menkveld, supra note 9, at 2.

198. Approval Order for NASDAQ, supra note 155, at 18,396; Approval Order for NYSE Arca, supra note 156, at 35,343; see also Letter from Joan C. Conley to Elizabeth M. Murphy, supra note 177, at $6 \mathrm{n} .23$ (arguing that "rather than a hard time limit the best measure is whether a product is successful from the liquidity perspective").

199. Of course, the integrated model is not by any means a new concept. For instance, in his description of the outdoor market of the late 19th century as a likely trading location for emerging companies, one commentator made the following observation:

There were several ways by which a broker could come to specialize in security, but the most common was to bring it to the market and stake a claim. Should a broker learn of a new mine being opened in the West, he might assist in its underwriting, keep a block of stock for his own account, and let it be known that he was prepared to "make a market" in that security.

Robert Sobel, The Curbstone Brokers: The Origins of the American Stock 
One conjecture is that services provided by a market maker cannot be easily unbundled, for instance due to information spillovers across different activities, ${ }^{200}$ which implies that the economies of scope exist. Some commentators even argued that market making in itself is an important source of information for other functions performed by investment banks. $^{201}$ Furthermore, there is some evidence that issuers do demand a bundle of services from securities firms. For instance, the notion that liquidity support is one of the key services offered by underwriters has some survey-based backing: “An underwriter's market making and trading desk services are an important consideration ... suggesting that post-IPO trading service is an important consideration in the up-front selection of an underwriter." ${ }^{202}$ From another perspective, there are conflicts of interest when market making is bundled with other functions, ${ }^{203}$ for instance, in the context of analyst recommendations. ${ }^{204}$ Another relevant consideration is whether a Chinese Wall would be a regulatory requirement even when the

EXCHANGE 87 (1970).

200. See Schultz, supra note 90, at 72; see also Leonardo Madureira \& Shane Underwood, Information, Sell-Side Research, and Market Making, 90 J. FIN. ECON. 105, 105 (2008) (arguing that "market makers whose banks also provide research coverage provide more liquidity and contribute more to price discovery than do market makers without such research coverage").

201. Alan D. Morrison \& William J. Wilhelm, JR., Investment Banking: Institutions, Politics, ANd LAW 9 (2007).

202. James C. Brau \& Stanley E. Fawcett, Initial Public Offerings: An Analysis of Theory and Practice, 61 J. FIN. 399, 412 (2006). On the other hand, the same study concluded that the provision of such services is not necessarily the decisive factor. See id. App. C, at 430. Furthermore, the obligation to provide liquidity support as a market maker is sometimes explicitly provided in contracts between underwriters and issuers, and, in fact, for a sample of NASDAQ IPOs, "the lead underwriter [was] always the dominant market maker." Katrina Ellis et al., When the Underwriter Is the Market Maker: An Examination of Trading in the IPO Aftermarket, 55 J. FIN. 1039, 1039-40 (2000). Another study provided empirical evidence "consistent with the hypothesis that underpricing is, in part, compensation [for underwriters] for expected post-IPO analyst coverage from highly ranked analysts [partly in connection with] their subsequent role as the primary market makers." Michael T. Cliff \& David J. Denis, Do Initial Public Offering Firms Purchase Analyst Coverage with Underpricing?, 59 J. FIN. 2871, 2871, 2875 (2004).

203. See generally Robert B. Thompson, Market Makers and Vampire Squid: Regulating Securities Markets After the Financial Meltdown, 89 Wash U. L. Rev. 323 passim (2011).

204. See, e.g., Jennifer L. Juergens \& Laura Lindsey, Getting Out Early: An Analysis of Market Making Activity at the Recommending Analyst's Firm, 64 J. FIN. 2327 (2009); Bruce Mizrach, Analyst Recommendations and Nasdaq Market Making Activity (Dept. of Econ., Rutgers Univ., Working Paper No. 2003-07, 2003), available at http://ssrn.com/abstract=499103; Hans G. Heidle \& Xi Li, Is There Evidence of FrontRunning Before Analyst Recommendations? An Analysis of the Quoting Behavior of Nasdaq Market Makers (Nov. 10, 2003) (unpublished manuscript) (on file with author), available

http://www.afajof.org/pdfs/2004program/UPDF/P177_Market_MicroStructure.pdf. 
true economies of scope are present. ${ }^{205}$

\section{B. Cross-Subsidization of Different Activities}

The integrated model of market making is a double-edged sword in the sense that market making may subsidize other activities undertaken by the same securities firm or vice versa. While a market maker may have additional sources of revenue in addition to its function of providing liquidity, such as underwriting and brokerage fees, ${ }^{206}$ some of its services in the course of promoting and supporting securities can be characterized as public goods. Additional revenues, such as underwriting fees, may ultimately come from issuers, but the key regular source consists of participants in the trading process.

There is some evidence that market making may have been subsidized by other activities. For instance one securities industry professional treated the abandonment of fixed brokerage commissions dating back to "Mayday" of 1975 as one of the factors "shrinking the profit opportunities for liquidity suppliers," 207 suggesting that cross-subsidization between brokerage and market making activities had existed on securities exchanges, as opposed to over-the-counter markets with no such price controls. $^{208}$ Another securities industry professional made a similar observation with a reference to the deregulation of brokerage commissions: "[E]xchange specialists had incentives to make bids and offers that would stabilize the market. At old commission levels, they could afford to provide liquidity during periods of stress .... [But] the specialist has seen a sharp drop in his floor brokerage." 209 On the other hand, one empirical study rejected the view that "providing liquidity and stabilizing the issues

205. For an empirical study that suggests the existence of leakages of confidential information through Chinese Walls of securities firms that engage in market making, see $\mathrm{H}$. Nejat Seyhun, Insider Trading and the Effectiveness of Chinese Walls in Securities Firms, 4 J.L. ECON. \& POL'y 369 (2008).

206. Sometimes, there are no separate charges for such services. See, e.g., Jeffrey W. Smith et al., The Nasdaq Stock Market: Historical Background and Current Operation 28 (Nat'l Ass'n of Sec. Dealers, Working Paper No. 98-81, 1998) (“[M]any Nasdaq dealers make markets primarily to service institutional clientele - these firms act as both broker and dealer to institutions. When an institutional investor trades with a market maker, it typically pays no commission.").

207. Burke, supra note 120.

208. For a discussion of the rise and fall of the fixed brokerage commissions regime on the NYSE and other securities exchanges and the lack of price controls on over-the-counter markets, see Stanislav Dolgopolov, Insider Trading, Chinese Walls, and Brokerage Commissions: The Origins of Modern Regulation of Information Flows in Securities Markets, 4 J.L. ECON. \& POL'y 311, 318-25 nn.26-67 (2008).

209. Louis Margolis, Before and After October 19: Structural Changes in U.S. Financial Markets, in InNOvation AND TeChNOLOGY IN THE MARKets: A REORDERING OF THE WorlD's Capital Market Systems 59, 63-64 (Daniel R. Siegel ed., 1990). 
in the aftermarket are "subsidized' by the underwriting activities."

The other end of the spectrum pertains to activities that must be subsidized by market making. For instance, although market makers have an interest in gathering and processing information about issuers, the cost of such activities is a limiting factor, and the availability of research reports by itself - especially when they are made available to the general publicmight not generate additional trading volume in order to be cost-efficient. Some commentators have favored a duty to produce securities research attached to market making: "Firms making markets in [the alternative trading market] would be required to provide equity research coverage that meets minimum standards, such as a thorough initial report, quarterly reports ... and forecasts." 211 This requirement to produce research reports has to be based on a set of privileges in order to recoup the applicable costs. $^{212}$

In fact, some commentators argued that the integrated model of market making has traditionally relied on trading revenues to support auxiliary functions: "The old NASDAQ bid-ask spread represented compensation to the industry for a complex bundle of services. These services included not only matching buyer and seller, but also for information production and dissemination that was useful to the market."213 A related point of view maintains that an alternative model of providing liquidity has been harmful to smaller-cap companies: "Evidence exists that low transaction costs in an 'execution only' environment can actually increase the cost of capital for smaller capitalized issuers because such costs fund the provision of research, marketing and sales information, as well as capital commitment, by intermediaries." 214 In retrospect, this rationale sheds some light on the "old" dealer markets and the detrimental

210. Ellis et al., supra note 202, at 1041-42.

211. David Weild \& Edward Kim, Grant Thornton LLP, A WaKe-Up Call for AMERICA (Nov. 2009), available at http://www.grantthornton.com/staticfiles/GTCom/Public\%20companies\%20and\%20capital $\% 20$ markets/gt_wakeup_call_pdf. It is useful to draw the distinction between "fundamental" analysis, which could be disseminated in order to attract outside interest in a given company's securities, and "technical" analysis, which is used for market making or proprietary trading.

212. For instance, designated market makers in smaller-cap stocks on the Italian Stock Exchange have the obligation "to produce at least two financial analyses each year, along with the presentation of the most recent available data, expectations about future economic results and a comparison with previous estimates [and] to organize at least twice per year meetings with professional investors." Pietro Perotti \& Barbara Rindi, Market Makers as Information Providers: The Natural Experiment of STAR, 17 J. EMPIRICAL FIN. 895, 897 (2010). In return, designated market makers are compensated by issuers, id., and this arrangement appears to improve market quality, id. at 896, although there is a visible conflict of interest with issuer-funded research.

213. Letter from James J. Angel to the SEC, supra note 131, at 7-8.

214. Letter from Eric Hess to Elizabeth M. Murphy, supra note 49, at 17. 
impact of several key developments on capital formation, and one of the principal concerns is the possibility that public limit order traders acting as de facto liquidity providers may free-ride on public good-type services provided by market makers.

\section{CONCLUSION}

The crisis of market making in smaller-cap stocks and its impact on capital formation illuminate the problem of externalities in the market for providing liquidity and the significance of the integrated model of market making. While not an exclusive or perhaps even the most powerful factor in the IPO decline, this market making crisis sheds some light on potential solutions, although the overall impact of their implementation is hard to predict. While aiming at greater competition and lower transaction costs in market making is important, the key goal is to provide incentives that encourage business models based on a dedicated two-sided provision of liquidity and an integrated value-added approach. "[A]n incentive-driven mechanism to support unknown and largely invisible companies (the vast majority of public companies) in the aftermarket for secondary liquidity" 215 is certainly needed to address some of the problems plaguing the capital formation process. Of course, rigorous empirical research on possible causation links among liquidity mechanisms, incentives for market makers, and capital formation is needed. This research should focus on the longterm effect and motivations of decision-makers, including surveys of securities industry professionals, venture capitalists, and business executives. After all, some variables in this nexus of causal links might be difficult to isolate and measure. Furthermore, some theoretical framework is needed to offer guidance on estimating socially optimal subsidies for providing liquidity.

Without idealizing securities markets of the past and their market makers or ignoring potential self-interest embedded in proposals advanced by the securities industry, the growing concern is that some desirable features of the capital formation ecosystem have suffered a blow. While reversing the ecosystem's evolution may be problematic, its re-design should involve a package of functionally similar and novel incentives for market makers, such as issuer-to-market maker compensation arrangements - without sacrificing the need to monitor and re-evaluate such incentives as a check on rent-seeking activities. Instead of an about face in the existing securities markets, which are increasingly dominated by high-frequency trading, such changes can be implemented at a new trading

215. WEILD ET AL., supra note 58, at 13. 
venue, ${ }^{216}$ although it is no easy task in itself. ${ }^{217}$ More generally, redesigned incentives for market makers could be a part of reforms leading toward greater control exercised by emerging companies over their securities' trading architecture and thus may counter potential negative effects. ${ }^{218}$ At the same time, uniformity in regulatory standards applicable to market makers should be approached with caution, although some harmonized principles are possible to prevent possible instances of a "race to the bottom." After all, "[m]arket making regimes are part of the commercial DNA of competitive venues," 219 and experimentation should be encouraged.

216. See, e.g., WEILD \& KIM, supra note 1, at 3; Tabb, supra note 129, passim. A recent recommendation to the SEC was to "[e]stablish[] a separate U.S. equity market specifically for the securities of small and emerging companies," but it was also suggested that "[a] possible feature of an appropriate regulatory regime for such a market would be limiting investor participation to accredited investors." Advisory Comm. on Small \& Emerging Cos., U.S. Sec. \& Exch. Comm'n, Recommendation Regarding Separate U.S. Equity Market for Securities of Small and Emerging Companies 1 (Feb. 1, 2013), available at http:/www.sec.gov/info/smallbus/acsec/acsec-recommendation-032113-emerg-co-ltr.pdf. For a recent discussion of other regulatory issues relevant for a trading platform for emerging companies, see Schwartz, supra note 22, at 580-93.

217. See, e.g., Reena Aggarwal \& James J. Angel, The Rise and Fall of the Amex Emerging Company Marketplace, 52 J. Fin. ECON. 257, 258 (1999) (describing a trading platform introduced by the American Stock Exchange as "one of many failed attempts to launch public equity markets for small stocks in the US and Europe").

218. See, e.g., House Hearings on H.R. 3606, supra note 26, at 48 (prepared testimony of Joseph Brantuk, Vice President, NASDAQ OMX Group) (declaring that "[i]t is time to consider allowing certain IPO companies, especially smaller companies using the public market to fuel growth, for a period of up to a year, to choose the market structure they feel would best introduce their stock to the marketplace."); see also Harris, supra note 136, at 19 (furthering that, "if corporations could specify the market structures for their stocks, the competition for listings would again become meaningful").

219. Letter from Andrew Bowley, Managing Dir., et al., Nomura Int'l plc, to Werner Bijkerk, Senior Policy Advisor, Int'l Org. of Sec. Comm'ns 4 (Aug. 12, 2011), available at http://www.iosco.org/library/pubdocs/pdf/IOSCOPD361.pdf. 